\title{
Collective Emotions in Institutional Creation Work
}

\author{
Steffen FARNY \\ Aalto University School of Business \\ Finland \\ steffen.farny@aalto.fi \\ Ewald KIBLER \\ Aalto University School of Business \\ Finland \\ ewald.kibler@aalto.fi \\ Simon DOWN \\ Anglia Ruskin University \\ UK \\ simon.down@anglia.ac.uk
}

Acknowledgments: We are greatly indebted to Gabi and Steve, and the people of Limonade, for their collaboration, openness and interest in sharing their stories. Without their trust, we would not have been able to immerse so deeply in understanding the emotions textures of everyday life in Limonade. Likewise, this research project would not have been possible without Erpo Heikkilä, Jerome Jouanno and Ritva Laurila (the ISO-team), who wholeheartedly accepted the ethnographer as a team member. We would also like to thank Prof Wendy Smith, the paper's editor, for her tremendously important guidance, and deep engagement with our work, throughout the entire review process. In addition, we are grateful for the candid, constructive and encouraging suggestions received from the three anonymous expert reviewers. Many thanks goes also to Nina Granqvist, Marc Gruber, Paula Kyrö, Helle Neergaard, Davide Ravasi, Sarah Robinson, and Eero Vaara for their feedback on earlier versions of the paper. 


\section{COLLECTIVE EMOTIONS IN INSTITUTIONAL CREATION WORK}

In this paper, we explain how and why collective emotions enable institutional creation work. Based on an ethnography in Limonade, a Haitian community affected by the 2010 earthquake, we identify social practices that elicit collective emotions through the creation of new institutions across the three disaster recovery phases. Our study's key insight is that new institutions converge collective emotions such that they in turn justify ongoing, as well as motivate engagement in new, institutional creation work practices. Theorizing from our findings, we develop a generative model that describes the justifying and motivating function of collective emotions in the establishment of embedded institutions. In conclusion, our paper advances theory on collective emotions in institutional work and generates implications for post-disaster management practice.

KEYWORDS: collective emotions, institutional work, natural disaster, ethnography, Haiti

"Never have I seen such motivation, determination, compassion and solidarity among people. When we entered Port-auPrince, the city had fallen and was continuing to fall as a result of continuous aftershocks. The streets were full of people sitting together. Everyone was sitting in the middle of the roads for fear that the houses would continue to fall on them. They were singing. The whole city was singing. They were singing songs of solidarity. They were singing songs of thanks and praise that they were still able to sing and to be together. These people have lost everything. [...] But they are putting their voices together to be thankful.” Amber Munger, US American human rights activist (Bell, 2013, p.20)

When Gabi woke up, the sound of singing was still in her head. But so was the pain, and all the destruction that surrounded her. The previous day she had walked through the dust and chaos of Portau-Prince until her legs couldn’t carry her anymore. During the $12^{\text {th }}$ of January 2010 earthquake, which locals simply call 'twelve', more than two hundred thousand people lost their lives, and around 1.5 million people were made homeless. As a result the already inadequate institutional capacity in Haiti completely disintegrated: 28 of 29 federal ministry buildings were damaged or had collapsed (Altay \& Labonte, 2014; Schuller, 2012; Zanotti, 2010). In the country's darkest hour, the Haitian government was invisible and impotent, and the international response, although vital in meeting immediate response needs, exacerbated weaknesses in the state's institutional capacity and ultimately further entrenched and deepened the cycle of international aid dependency (Bell, 2013; Katz, 2013; United Nations, 2011). At the same time, a wave of Haitians helping each other emerged as a noteable feature of the disaster response. In the weeks and months that followed the quake, Haitians provided food, shelter and emotional support to six hundred thousand internal refugees: "The tremendous chain of solidarity we saw from the day of the earthquake on: that is our capacity. That is our victory. That is our heart.” (Bell, 2013: 26, citing Yolette Etienne, Oxfam Haiti program). Our paper draws on this 
less explored side of Haiti's earthquake recovery, in which local citizens and social entrepreneurs Gabi and Steve became important post-disaster agents, helping to mobilize collective emotions and build new institutions.

Management research on post-disaster organizing has begun to provide important insight into the effectiveness of local initiatives in addressing survivors' immediate needs. At the same time, these researchers have called for studies that are able to develop an understanding of local practices supporting post-disaster community recovery in the medium to long-term (Shepherd \& Williams, 2014; Williams \& Shepherd, 2016). We address this by examining the under-explored role of institutional work, i.e. the creation, maintenance or disruption of institutions (Lawrence \& Suddaby, 2006). Specifically, we view institutions as social arrangements constituted by social practices (Lawrence, Suddaby, \& Leca, 2009; Smets, Jarzabkowski, Burke, \& Spee, 2015; Vaara \& Whittington, 2012), which in turn guide social life "by providing templates for action, cognition, and emotion” (Lawrence, Suddaby, \& Leca, 2011: 53). In disrupted contexts new social practices are needed because previous templates for organizing social life don’t work anymore (Marquis, Glynn, \& Davis, 2007; Zietsma \& McKnight, 2009). Local communities affected by natural disaster need positive emotional experiences to spur collective efforts for post-disaster recovery, because negative, sometimes traumatogenic, experiences can paralyze everyday social life (Dutton, Worline, Frost, \& Lilius, 2006; Paton, 2006; Vázquez, Cervellón, Pérez-Sales, Vidales, \& Gaborit, 2005).

With these observations in mind, our central argument is that effective post-disaster community recovery needs social practices that mobilize shared emotional responses into the creation of new institutions (Moisander, Hirsto, \& Fahy, 2016; Voronov \& Vince, 2012). To demonstrate this we build on theorizations of "social practices in the elicitation of collective emotions" (von Scheve \& Ismer, 2013: 412) and thereby integrate collective emotions into recent advances on emotions in institutional work (Lok, Creed, DeJordy, \& Voronov, 2017; Voronov, 2014; Zietsma \& Toubiana, 2018). Accordingly, we define collective emotions as emotions that are shared by individuals in a 
certain group or community (Bar-Tal, Halperin, \& de Rivera, 2007; de Rivera \& Páez, 2007; Salmela \& Nagatsu, 2016): they are visible in gatherings, crowds or widely salient events where there is congruence in people’s affective responding (von Scheve \& Ismer, 2013; von Scheve \& Salmela, 2014). Based on these theoretical assumptions we ask how do collective emotions enable the creation of institutions?

We address this question by presenting a punctuated five-year ethnography which investigated social practices of local agents supporting community development and creating institutions across post-disaster relief, recovery and reconstruction phases (Lizarralde, Johnson, \& Davidson, 2010; Paton, 2006; Quarantelli, 2005). Our study is based on four separate field trips, examining the daily social practices in a community in Haiti called Limonade. Extreme settings-in the sense that the earthquake had an extremely negative and transformative impact on all aspects of the communityprovide a vivid context that make shared emotions, otherwise difficult to capture, more visible (Hällgren, Rouleau, \& de Rond, 2018; von Scheve \& Ismer, 2013). Hence, Limonade is a useful empirical setting to ethnographically investigate the role of collective emotions in institutional work. Expanding on the current conceptual work that seeks to move beyond the emotions of key individual institutional agents (Lok et al., 2017; Zietsma \& Toubiana, 2018), and research focusing on shared emotions shaping fields or discursive political spaces (Moisander et al., 2016; Voronov \& Vince, 2012), we examine the collective emotions among community members which underpin their local institutional work.

In summary, our study demonstrates how people practice institutional creation work via mobilizing collective emotions. In particular, we expand the institutional work perspective by explaining how and why collective emotions justify and motivate institution building. Taken together, our paper opens up a new space for future research on the relationship between institutional work and collective emotions, and discusses several implications for post-disaster management practice. 


\section{THEORETICAL GROUNDING}

\section{Institutions, Social Practices and Collective Emotions}

Institutions are more or less enduring social arrangements founded by social practices (Lawrence \& Suddaby, 2006; Smets et al., 2015; Vaara \& Whittington, 2012). They guide everyday social life and provide important templates for individual and collective behavior, cognitions, and emotions (Lawrence et al., 2011; Lok et al., 2017; Zietsma \& Toubiana, 2018). Institutional theory has argued that social practices forming institutions are driven by agents' cognitive rational interests (Lawrence \& Suddaby, 2006; Scott, 2014). Recently, theorists have drawn particular attention to the emotional aspects of institutional formation (e.g. Fan \& Zietsma, 2017; Friedland, 2018; Grodal \& Granqvist, 2014; Moisander et al., 2016; Ruebottom \& Auster, 2017; Voronov, 2014; Voronov \& Vince, 2012; Voronov \& Weber, 2016; Wright, Zammuto, \& Liesch, 2017). Symbolic of this development, Creed et al. (2014: 279) have argued that "people are not exclusively emotional any more than they are exclusively cognitive, and institutional theorists should refuse to mischaracterize people as merely either rather than both”. Consequently, neo-institutional analysis increasingly views emotions as integral, where rational reasoning and emotional experience mutually shape each other and social practices (Creed et al., 2014; Fan \& Zietsma, 2017; Friedland, 2018).

Emotions are the conscious and unconscious affective appraisals and subsequent experiences of individuals or groups (Bar-Tal et al., 2007; Turner, 2009; von Scheve \& Salmela, 2014). They accompany all action, both as motivation and goals (Jasper, 2011). They are connected to everyday behavior and influence and are shaped by the social situations within which they occur (Fan \& Zietsma, 2017; Grodal \& Granqvist, 2014; Lok et al., 2017). Emotions tie us to institutions, and institutions, in turn, shape the way we feel (Friedland, 2018; Zietsma \& Toubiana, 2018). As such, the emotional experiences of actors play a role in creating, maintaining and disrupting institutions, i.e. practicing institutional work (Lawrence \& Suddaby, 2006; Lawrence et al., 2009; Scott, 2014). 
Voronov and Vince’s (2012) theoretical work and its recent development by Moisander et al. (2016) are the most significant advances in our current understanding of shared emotions in institutional work (Zietsma \& Toubiana, 2018). Voronov and Vince (2012) combine psychoanalytical theory with Bourdieu's (2000) concepts of capital and habitus to theorize on how shared emotional investments in the institutional order enable the change of field-level arrangements. Moisander et al. (2016) apply Hochschild's (1979) dramaturgical approach to emotions to suggest how the strategic social construction of emotional expressions in policy texts underpins institutional work. Both of these conceptualizations are theoretically grounded in the sociology of emotions (Turner, 2009) which emphasize emotions as socially constructed, collective phenomena which underpin institutional work, rather than presenting emotions as solely individual responses to institutions.

Further, recent studies in the theory of collective emotions (Salmela \& Nagatsu, 2016; von Scheve \& Ismer, 2013; von Scheve \& Salmela, 2014) that are consistent with a social practice approach (Lawrence \& Suddaby, 2006; Lawrence et al., 2009; Smets et al., 2015), explain collective emotion elicitation as rooted in physically proximate and culturally embedded social practices (von Scheve \& Ismer, 2013). In particular, for “collective emotions to emerge, individuals have to appraise an event in similar ways, which in turn requires a minimum of shared appraisal structures or shared concerns and leads to convergence in emotional responding” (von Scheve \& Ismer, 2013: 412). Therefore, institutional work is bound to the social embeddedness of its practices and to the convergence of affective responding, which require analyses of the interplay between collective emotions and social practices in understanding the constitution and generation of institutional arrangements (Lok et al., 2017; Voronov \& Vince, 2012; Zietsma \& Toubiana, 2018).

\section{Natural Disaster, Community and Collective Emotions}

A natural disaster occurs when an external hazard (e.g. an earthquake) strikes in places where people live (Perry, 2009; Quarantelli, 2005). Places are “combinations of location, material form, and sets of meanings and values. [... They] are socially constructed, with people [...] performing those 
places and thus continuously revising and reconstructing” social arrangements (Lawrence \& Dover, 2015: 373). Hence, while institutional fields and discursive spaces are rather ambiguous, potentialdriven and future-oriented (Grodal \& Granqvist, 2014; Zietsma, Groenewegen, Logue, \& Hinings, 2017), places are people-centered and the communal product of longer cultural histories (Gieryn, 2000).

After natural disasters, local community arrangements are substantially disrupted and often no longer taken-for-granted (e.g. materiality, symbolically) (Marquis, Glynn, \& Davis, 2007). Likewise, institutionalized templates for local organizing likely become insufficient (Seo \& Creed, 2002; Zietsma \& McKnight, 2009). Such institutional degradation encourages bottom-up social practices (Barley \& Tolbert, 1997; Fan \& Zietsma, 2017) that create new local templates for immediate postdisaster organizing (Williams \& Shepherd, 2016). Hence, emergent post-disaster practices tend to substantially diverge from previously established organizing routines (Drabek \& McEntire, 2003; Shepherd \& Williams, 2014). This is achieved by people "reinterpreting the past, responding differently to present concerns, and envisioning the future in innovative ways” (Kaplan \& Orlikowski, 2013: 991).

The initial reference point of post-disaster organizing beyond the provision of immediate physical needs, is the immediate collective negative, sometimes traumatogenic, emotional experience of those affected (Norris, Friedman, \& Watson, 2002; Sneath, Lacey, \& Kennett-Hensel, 2009; Vázquez et al., 2005). Despite the need for recognizing and ameliorating traumatogenic experiences, post-disaster research has also stressed the importance of understanding organizing practices as enabling positive emotional experiences that foster joint action for community recovery (Fredrickson, Tugade, Waugh, \& Larkin, 2003; Paton, 2006; Vázquez et al., 2005). Building on the theory of collective emotions, we argue community recovery requires social practices that make use of “physical proximity promot[ing] emotional contagion between individuals” (von Scheve \& Ismer, 2013: 407). Hence, our study moves the focus of collective emotions in institutional work targeted at 
shaping instutional fields (Voronov \& Vince, 2012) or discursive political spaces (Moisander et al., 2016) to an analysis of collective emotions among community members underpinning their local institutional work over time.

\section{EMPIRICAL CONTEXT: HAITI AFTER THE 2010 EARTHQUAKE}

"This country has the best chance to escape its past than it's ever had... As horrible as this is, it gives them a chance to start again.” (Bill Clinton, Head of Haiti Interim Recovery Commission and former US-president, March 2010)

Haiti is widely known as a 'failed' state, which became particularly visible in the lack of local governing capacity in the response to the 2010 earthquake (Bornstein, Lizarralde, Gould, \& Davidson, 2013). Post-disaster research emphasizes that natural disasters of this magnitude accelerate pre-existing social, economic and political trends (Abrahams, 2014; Kates, Colten, Laska, \& Leatherman, 2006; Lizarralde et al., 2010). The recurrence of natural disaster in Haiti amplified a more general institutional instability (Altay \& Labonte, 2014), and not surprisingly, post-disaster recovery plans have identified weak governance as an obstacle to effective post-disaster response (Bornstein et al., 2013).

Despite the initial disaster response (10-15 weeks) being slow and overly militarized (Walker, 2011), most observers agree it was adequate (Biquet, 2013). However, commentators have suggested that the recovery and reconstruction phases were deficient (Bell, 2013; Katz, 2013; Schuller, 2012). One reason is the low institutional preparedness of the Haitian government with the international disaster response system. Some have even argued that as a result of inadequate integration of local institutions, the international response system might have actually aggravated the situation (Biquet, 2013). Figure 1 illustrates how the international response in Haiti introduces additional institutional instabilities and poorly manages local expectations beyond the initial emergency response phase. Therefore, our empirical focus emphasizes the practices of local response groups since they often act before institutionalized bodies reach an agreement on a course of action (Majchrzak, Jarvenpaa, \& Hollingshead, 2007). 
Insert Figure 1 about here

The empirical site for this research is the small town of Limonade (pre-earthquake population size: 14886, IHSI, 2009), located in the Department Nord. Due to the significant internal refugee flows after the earthquake, Limonade’s population has substantially increased (20281, IHSI, 2015). Limonade has a very young population which comprises of families subsisting on artisanal and agricultural work, mostly living in rural areas. Since Limonade did not possess any educational infrastructure beyond high school and generally lacks employment opportunities, absorbing 5000 internal refugees was a substantial challenge. While the town experienced only minor damage to its physical infrastructure, the earthquake had a profound impact on the whole country. The Mayor of Limonade summed up the post-disaster situation: "The earthquake hit everybody, because in all the 140 communities everybody lost someone. [...] Now, what happened, everybody who had relatives in the provinces returned [from the capital]. Like, there was young people from Limonade who died, and those who had broken legs and who were traumatized".

\section{METHODS}

Our ethnographic study aims to develop an understanding of how collective emotions enable the creation of institutions. To achieve this we adopted a naturalistic mode of inquiry and followed an inductive logic, focusing on the same circle of key agents which facilitated examination of emerging institutional work practices over five years (de Rond \& Lok, 2016; Granqvist \& Gustafsson, 2016; Williams \& Shepherd, 2016).

\section{Data Collection}

Our data collection comprises of an extensive range of empirical materials gathered between 2011 and 2016, by one of the authors, hereafter referred to as "the ethnographer" (see Table 1). Following the ethnographic tradition (e.g. Geertz, 1972), field data was collected through field visits at a single geographical site in multiple rounds, quite common in ethnographic practice (de Rond \& 
Lok, 2016; Down \& Reveley, 2009). Practices of local agents were observed as they occurred, generating data in the form of observation notes, interviews, and from documentary sources. As part of a research project, partly funded by an international support organization (ISO), and initiated by Sonje Ayïti Organization (co-founded and managed by Gabrielle Aurel and Steve Astrel Mathieu), the Mayor of Limonade had asked the international community for help in scoping the development potential of the community. The ethnographer's reasons for joining the project as a volunteer were on the one hand practical, to get access to locals to generate a rich research database for writing a doctoral dissertation, and altruistic, to learn from and participate in a project oriented towards sustainable change.

For this ethnographic study, we were able to secure access to Sonje Ayïti, and entrepreneurs Gabi and Steve, who played a central role in the collective disaster recovery of the community. As key institutional workers, Gabi and Steve intended to create better institutional arrangements by mobilizing collective effort (Voronov \& Vince, 2012). Already before the 2010 disaster, they were helping their fellow Haitians in Limonade, first from the US, but since 2006 and 2007 collaboratively and predominantly on-site. They are of Haitian descent but grew up in Georgia, US. Steve is very explicit about his intentions: “in the US, I didn’t fulfill my dream. I have to be back here where my education can be of help to the society”. Despite having solid jobs as civil servants in Atlanta, Gabi expresses their dedication to Limonade:

"we started Sonje Ayïti in 2004 in Georgia as a moral obligation. I lost my mother when I was only 5: she was taking the boat to go to the United States. And to me, because of my Dad, I never had to fight, to struggle. [...] This is for me something I cannot take for granted, because when I look through the eyes of another Haitian woman like me, the only thing that differentiates me from her is that because of the green card my Dad provided to me, I had opportunities she never had. [...] To me, starting with Sonje Ayïti, and not being there to empower was giving them a different message. Encouraging them to dream in Haiti, you can make it in Haiti and not be in Haiti, it was just like I was just preaching to the world, but I was not living up to it”

Together they co-founded Sonje Ayïti, literally 'Remember Haiti', the food production enterprise SAPENSA (Société Agricole de Production et d’Élevage du Nord, S.A.), the Anba Tonel Restaurant and fostered the formation of two farming cooperatives. 
Sonje Ayïti’s long standing efforts in Limonade provided the ethnographer with unique access to post-disaster community development. The organization hosted the ethnographer during the field trips and facilitated engagement with a number of important community recovery actors, such as regional politicians, business actors, educators, and volunteer groups. Hence, Sonje Ayïti’s credibility was crucial in building trust within the local community. For instance, building wooden toilet centers together with 20 workers from the community for a week (field trip 2) was crucial for the ethnographer to turn from an 'outsider' status to eventually become an accepted member (see Table 1). It was due to the ethnographer's physical and emotional immersion that a more situated understanding of the practices was achieved:

“Today was a nightmare. At night a group of armed men broke into the house and kidnapped Gabi's daughter. Luckily, an hour later she was released and sent back home. Next morning, we went to the police. We sat waiting in a shabby ill-equipped room, while outside a Voodoo ceremony was taking place as if it was totally normal. It was, here, but for me it was captivating and repulsive all at the same time. Filming this bizarre scene helped dissipate my shock, and at one point I remember Steve saying to me: 'now you know why it is so important to involve the community in everything we do'. I finally understood what he meant and also what it feels like to try to change things in Haiti.” (field notes)

Insert Table 1 about here

Participant observation and interviews. Overall, the ethnographer spent 41 days investigating post-disaster institutional work practices in Limonade. The fieldwork took place in four phases, each of which was spent in the community, living with Steve and Gabi’s families. Formal semi-structured interviews with several entrepreneurs, employees and affiliates of Sonje Ayïti, the Mayor, and local experts — for instance, at the university — were conducted during those trips. These facilitated further in-depth insights, complementing the iterative and cumulative nature of the fieldwork. Most of the interviews with local staff and community members were done in Creole with the help of a foreign translator, who had joined parts of the fieldwork, and afterwards provided the transcriptions. Some of the interviews, as well as respondents’ daily work practices, were videoed. In all, 1897 photographs and twelve hours of film were compiled and edited into a short film (details of which are publicly 
available here: https://vimeo.com/36593964), which helped the broader research team of co-authors and advisors experience the field indirectly.

Informal conversations and observations during the field trips proved to be another rich data source. They helped deepen our understanding of situated post-disaster practices and were noted in a field diary on a daily basis. Thanks to the international aid project and ISO personnel the ethnographer also gained useful access to high-level governmental meetings (e.g. observations of meetings with the EU-commissioner in Haiti, the Haitian President, the Prime Minister, and staff of the Interim Haiti Recovery Commission). Specifically, this helped situate the data (and disaster recovery literature) in the context of the broader international response. The fieldwork also included participation in project meetings with a group of 40 entrepreneurs as well as university students in Limonade. This enabled an examination of the collective efforts across the entire five years of research. Further, email and mobile messaging with Gabi and Steve, as well as meetings with ISO staff helped to triangulate information and further deepen our understanding. These regular exchanges strengthened the analysis as it confirmed our preliminary finding that daily social practices changed as post-disaster recovery and reconstruction progressed (see Figure 1).

Secondary and documentary data. In addition to the field visits, the ethnographer researched particular and general aspects of the Limonade recovery situation full time over 18 months between January 2011 and July 2012. Considering the nature of the post-disaster context, communicating with the field, gathering data at a distance, and seeing how the impact of daily social practices evolved over time significantly enhanced the ethnographers understanding of the collective creation of post disaster institutional change. We also drew on project documents, email correspondence, government reports and media coverage. In all 833 emails and 13 folders of project documents about Sonje Ayïti, SAPENSA and other recovery initiatives in Limonade were collected, and incorporated into the broader data analysis (e.g. business plans, project documents, reports, application/funding filing). Additionally, a total of 12,000 pages of reports by UN-led international development agencies (e.g. 
needs assessment, development strategy, charts, information packs, newsletter) and more than 1500 media articles during 2011-2016 (e.g. from Haiti Libre and Miami Herald - the only major American daily newspaper to dedicate a regular section to Haiti), and the Haiti Relief and Reconstruction Watch blog (HRRW) were read and helped to better understand post-disaster practices and contextualize the primary data.

\section{Analytical Procedure}

Making credible theoretical inferences during the analytical process in ethnographic studies is particularly challenging (de Rond \& Lok, 2016; Locke \& Golden-Biddle, 1997; Mantere \& Ketokivi, 2013). To make use of the full potential of ethnographic data, our data analysis combined interpreting ethnographic insights with inductive theory-building procedures, going back and forth between data, emerging themes and existing theoretical concepts (de Rond \& Lok, 2016; Eisenhardt, Graebner, \& Sonensheim, 2016; Stigliani \& Ravasi, 2012). Creating new, plausible connections between data and existing theory thus follows a cyclical process, continually questioning our interpretation and problematizing our data structure in light of the extant literature (Alvesson \& Karreman, 2007; de Rond \& Lok, 2016; Locke \& Golden-Biddle, 1997). Instead of following a linear, step-by-step analysis, our analytical process inferred from the ethnographer's data collected and personal experiences to iteratively abstract the data until we achieved a credible and persuasive explanation of the observed institutional work.

Sketching the observation ground. The analysis process began with several rounds of discussions around the ethnographer's observations and experiences. Going carefully through the photos, videos, interviews and field notes, the author team developed an initial shared understanding of Limonade’s post-disaster recovery to situate community actors, activities and events. In particular, possible interpretations of meaningful post-disaster events, such as building new toilets or rebuilding a chicken farm, helped us move from understanding 'natural' post-disaster consequences, such as individuals' emotional suffering and traumatogenic experiences (Vázquez et al., 2005), to an 
understanding of how community members showed positive reactions needed for post-disaster community development. For example:

"Because after all the efforts - and we did all the efforts together - we showed them that we have the will. Sonje Ayïti had a team which didn't sleep, they worked day and night. And when we finished working we met with the people and we said: today we have given them life, we wish that tomorrow they will give us life through their collectivity. [...] This made us increasingly realize that Haitians can work. And we put in the spirit of every Haitian, that collectivity is the key issue.” (Patrick, a worker of Sonje Ayïti)

Since statements like these kept re-appearing, sketching the observation ground revealed the importance of positive collective responses as a key point of interest worthy of further detailed analysis. This meant a focus on how community members collectively engage in the creation of new institutional arrangements. Following this, we continued with interpretative analysis of new institutional arrangements in Limonade as well as on the community members' social practices creating those community arrangements.

Identifying new institutional arrangements. In this analytical step, we developed a detailed abstraction from the data (Granqvist \& Gustafsson, 2016) in the form of new post-disaster institutional arrangements created in Limonade. These are the more or less enduring community arrangements that guide everyday social life and provide important place-based templates for individual and collective behavior, cognitions, and emotions (Lawrence, Suddaby, \& Leca, 2011). In our analysis, we first employed an 'insider/outsider' coding method, in which the ethnographer and an author who had not been involved in coding the original field data re-coded data into categories (Corbin \& Strauss, 2008). This analytical procedure offered our team a way to both secure intimacy with, and critically reflect on, the post-disaster community setting (Langley, Smallman, Tsoukas, \& Van de Ven, 2013; Lok \& de Rond, 2012).

Moving forward in our abstraction, we built on place-based institutional work research (Lawrence \& Dover, 2015) to understand community arrangements as meaningful cognitive, symbolic and physical institutional arrangements in Limonade. We revealed that disaster 
assessments, needs for better healthcare support and needs for communication infrastructures $\left(1^{\text {st }}\right.$ order categories) all describe the creation of a new collective awareness ( $2^{\text {nd }}$ order theme), reflecting a form of cognitive institutional arrangement that helps structure perceptions of a disaster-struck environment. Cognitive institutional arrangements are defined as beliefs about the expected standards of behavior specific to a local cultural setting (Scott, 2014). Similarly, we found that the creation of collective trust in Limonade reflects a form of symbolic institutional arrangement, defined as the local norms that, when managed, exercise symbolic power for substantive action (Emirbayer \& Goldberg, 2005; Hallett, 2010). Further, we observed temporary and enduring physical infrastructure (e.g. toilets, school, farm, university) influencing communal life. A common feature of collective awareness, collective trust, and four other second-order themes (see Table 2a) is that they create a shared understanding of routinized and legitimized behaviors, which effectively makes them an institutional arrangement (Schatzki, 2005).

Insert Table 2a about here

Identifying post-disaster social practices. Following the institutional work approach, our analysis drew particular attention to mundane post-disaster social practices that helped create new institutional arrangements (Dover \& Lawrence, 2010; Lawrence \& Suddaby, 2006). In this step, we first built on the established distinction (Lizarralde et al., 2010; Paton, 2006; Quarantelli, 2005) between disaster response (phase 1), recovery (phase 2) and reconstruction practices (phase 3) to develop a temporal understanding of social practices. Such temporal bracketing of the data into "successive adjacent periods enables the explicit examination of how actions of one period lead to changes in the context that will affect action in subsequent periods.” (Langley, 1999: 703).

Following an open and axial coding process of the data in accordance with the post-disaster phases, we iterated the base of the coding scheme to reach consistency in our first and second-level of abstraction (Shepherd \& Williams, 2014; Smets et al., 2015; Stigliani \& Ravasi, 2012). Beyond its 
descriptive utility, temporal bracketing also frames comparative units of an ethnographic analysis in a way that helps in identifying the most relevant institutional work practices (Lok \& de Rond, 2012). For instance, we observed that, in the emergency response phase, Gabi and Steve are able to lead and advocate for local people and social projects, as well as to improvise with existing and new material resources ( $2^{\text {nd }}$ order theme). In the post-disaster recovery phase, we observed them collaborating with other local and international actors, valorizing the new support practices and reflecting on postdisaster social practices. Additionally, our analysis linked social practices to new institutional community arrangements in order to examine if institutional creation work in one phase lead to new institutional arrangements in the next. For instance, social practices that created collective awareness in the disaster response phase, seemed to enable the application of a different set of post-disaster practices, developing collective trust among community members, in the subsequent recovery phase.

Based on the circular coding across the post-disaster phases, we achieved greater accuracy in explaining which social practices create relevant institutional arrangements (Langley, 1999). With the help of NVivo10 this iterative process resulted in ten post-disaster social practices that were key to create new institutional arrangments across the three post-disaster phases (see Table 2b). This data analysis also showed that those social practices addressed community members' emotional coping with and subsequent recovery from the disaster, since having to deal with the shared traumatogenic consequences of the disaster seemed unavoidable: "there are so many people, when they hear a noise, they automatically jump up and look for shelter” (Ernise, teacher). Following this, we therefore added another analytical step tracing shared emotions.

Insert Table $2 \mathrm{~b}$ about here

Tracing shared affective responses. Our analysis still lacked an understanding of shared emotional experiences, mobilized through distinct institutional work practices in the different postdisaster phases. Since emotions are a collective phenomenon, but remain a property of individuals 
(Halperin, 2014; Pacherie, 2014; Salmela \& Nagatsu, 2016), we were able to analyze our data to distinguish differences in affective responses. This builds on the theory of collective emotions, which suggests shared affective responses exist as attractions and repulsions between people (de Rivera, 1992; von Scheve \& Ismer, 2013; von Scheve \& Salmela, 2014).

Sometimes affective responses were implicitly expressed through the use of symbols as well as more explicitly in interview narratives. For instance, collective hope was represented through strong symbols in social practices during the post-disaster recovery phase: 'Community School of Hope' printed in large letters on the school building; workers on the toilet construction site wearing yellow t-shirts signaling 'strong hygiene knowledge warrants health’ (konesans sou lijyèn = lasante blayi, lapwòpte garanti), and Gabi often mentioning how important it was to “instill hope”. We realized that focusing on hope as an emotion has the benefit of expressing shared concerns, encouraging people to cooperate and engage (Shin, Taylor, \& Seo, 2012). Through axial coding (compare Table 2c) and constant comparison with the literature on emotions, we revealed six distinct collective emotions in our data (confidence-de Rivera, 1992; feeling of security_de Rivera, Kurrien, \& Olsen, 2007; compassionate empathy—Dutton et al., 2006; affective solidarity—Jasper, 2011; hope—Shin et al., 2012; and harmonious passion-Vallerand et al., 2003). This iterative process has supported our argument that elicitation and convergence of people's affective responses helps to explain the role of newly created institutional arrangements for collective emotions. In Figure 2, we provide an overview of the resulting data structure emerging from our analysis.

Insert Table 2c and Figure 2 about here

Connecting to the theory of collective emotions helped us further distinguish two mechanisms in explaining how collective emotions enable the creation of new institutions: collective emotions justifying current social practices and collective emotions motivating new social practices (Salmela \& Nagatsu, 2016; Tuomela, 2013). Going back and forth between the data and theory, we realized 
that feeling of security, affective solidarity and collective confidence primarily justify and thereby legitimize current social practices, whereas compassionate empathy, collective hope and harmonious passion motivate community members' engagement in new institutional creation practices (Salmela \& Nagatsu, 2016). Since we were not always able to directly observe the mechanisms of collective emotions among Limonade's community members in their daily practices, we employed a narrative strategy to construct detailed stories from the data (Langley, 1999) that assist in making analytical inferences from the observable institutional work practices, institutional arrangements and collective emotions. Through descriptive narratives, or realist tales (Van Maanen, 2011), we could capture “vicarious experience” of the post-disaster setting in all its richness and complexity (Langley, 1999: 695). For instance, video data from visiting an improvised school made out of a UNICEF tent showed us that the feeling of security generated by the school reflects elicitation of and convergence in affective responding.

\section{INSTITUTIONAL CREATION WORK IN THE LIMONADE COMMUNITY AFTER THE}

\section{JAN 12, 2010 EARTHQUAKE}

As a result of the data analysis process, our ethnography of Limonade shows that collective emotions shape institutional creation work in a disaster-affected local community. In the following, we explain the process of institution building across the three disaster recovery phases in Limonade. Specifically, for each phase, we first describe the mechanisms how collective emotions enable institution building with the help of ethnographic vignettes, and then emphasize construct clarity by providing additional data to explicate the themes underpinning the institutional creation work process. We conclude our findings section by developing an institutional creation work model that explains why the justifying and motivating functions of collective emotions shape institutional creation work.

\section{Institutional Creation Work in Post-Disaster Response Phase (January - Fall 2010) \\ Vignette I: Makeshift School Helps Displaced Children and Parents Feel Secure. It is dripping humid and more than 30 degrees in the shadow. I am taking a sip of water as we step into what is}


basically a tent. How can this be a school? Inside, a group of kids, both villagers, displaced families and orphans, jump up excitedly shouting 'hello Gabi, hello, hello!'. One of the teachers approaches Gabi and me, hugs her and starts telling me how great it is to have a new school in the community. The 'school' is an old, repurposed UNICEF tent, a donation collected by Sonje Ayïti at the end of summer 2010. I am so hot and dripping with sweat I can hardly breath. Fortunately, the conversation with the teacher keeps me focused. She confirmed my intuition that it was Sonje Ayïti (represented by Gabi and Steve) who collected and improvised the basic school materials, asked local families to build chairs and tables, and looked for donations to pay the volunteer teachers. The very fact of the school being established seemed to create a feeling of greater security among the children and their parents. With the tent school, every morning the parents get their kids ready for school and the village comes together at the school, the jumble of peoples' emotions also converge and an emerging sense of people feeling safe again is palpable. As Gabi tells me: “even though the community has no other resources, they have two teachers, and they said they are going to make this happen... Otherwise the kids would have to walk three miles to the closest school, and kids can't really do that now. So the community takes charge, they want to change the situation by putting this tent to good use, but eventually build a school for those children”.

Community members' shared feelings of security allowed normal life to start moving again, and provided Gabi and Steve positive feedback to continue advocating for people on who needs to do what and to improvise with spare wood to build school furniture. So, with the help of the children's parents, the tent-school that has been built in a neighbors' backyard, soon gets equipped. The school is popular with its 80 students (split into two shifts of 40 kids) squeezed under a 24 sqm roof. The grass has worn away. Chairs and tables stand directly on the compacted earth floor. To allow for some air circulation, the tent has been elevated so that it is suspended above the floor on all sides. Like schools everywhere pictures painted by the kids representing the letters of the alphabet are pasted onto the wall. A local villager temporarily acting as the teacher smiles while empathetically 
explaining "it is not because this is the right condition, but we are obligated to teach like this, because the kids need schooling. That's why you see a school in this state here” (see Figure 3). Several parents are also stood busying themselves in the tent, ready to help out whenever needed. With the school established, people have a new meeting place where new and old villagers come together, sharing stories, laughing and crying, learning about how the disaster affected them. Through this new awareness people started caring for each other. A few weeks later, Gabi sends me an email reflecting upon how the school motivates the villagers to be even more engaged: "the people say, this is just the beginning, more resources need to be collected and the school needs to be integrated into the schooling system, with permanent teachers, a proper curriculum and so on.”

The new tent school helped community members (including the influx of earthquake affected internal refugees) to develop collective feelings of security that provides villagers with reasons to approve, justifying ongoing improvising, assessing needs, leading and advocating practices. Through increasingly collective engagement in creating new awareness (e.g. a desire to see their children going to school; continue being safe), villagers also developed greater empathy for one another, motivating Gabi and Steve to begin collaborating with new actors, moving on to new things: there was lots to do.

Insert Figure 3 about here

Increased Collective Awareness Activates Villagers' Compassionate Empathy to Engage in Disaster Recovery. The post-disaster response begins with Gabi and Steve improvising with available resources to alleviate suffering and create temporary material solutions. The vignette above is typical of what we saw happening: the re-establishment of schooling is an important disaster response initiative among key community actors. By improvising Sonje Ayïti showed how families could build furniture and cobble-together school materials from the city. Since no teachers lived locally, Gabi and Steve went to Cap-Haitian, a city 30 minutes away, to find teachers that would at first be paid through donations from the US, all in order to quickly instill a feeling of security, which is typically 
induced by the supply of basic goods and services (De Rivera, Kurrien, \& Olsen, 2007: 257). Postdisaster environments are heavily resource constrained requiring agents to be creative and improvise. In another example, Sonje Ayïti was able to refit a small school bus into a mobile psychological support clinic.

"So Sonje Ayïti put a mobile clinic here, above all in the first section [local neighborhood], and after that they started to give consultations every Friday, give medication and speak with people [...], to talk with them and help them rationalize what had happened, so that they would not be too traumatized” (Ernise).

Supporting the creation of material solutions during the first weeks following a disaster, institutional creation work further consists of assessing needs, advocating on emergent roles, and leading local response efforts, which conjointly sharpens a community’s collective awareness. As Patrick, a single parent with one child, who embraced the call to volunteer and hosted several internally displaced people, explains,

"Sonje Ayïti would come to see you and if you have a house they would ask you to provide shelter for a group of people. And then, every week they would come by and bring food. They went to the school and made investments to help children go to school; this is exactly how it went. And then they established the housing program. Sonje Ayïti went around and asked every single person if they were in the 12 [earthquake] and went with the list to Mayor Manguira in the Mayor's office in the local council, and every single person was donated a house or lodging of some sort.”

After assessing the survivors' psychological needs Gabi clarifies that "we also hired a psychologist for three months [for] those people who lost family members and who were traumatized”. Identifying needs by being resourceful with available resources meant that customized solutions were found. Furthermore, Gabi and Steve were able to combine a material response in the form of food and shelter with strong leadership. Gabi explains her approach to addressing the many problems:

"There was no so-called leader to really help coordinate. I remember we met with Konbit Santé, Food For The Poor, and some other NGOs. We sat to see how we can organize that to put some order inside. [...] We had some donations from France, we had some dried fruits, some toiletries, like hygiene products. We were able to go to different houses. Instead of doing mass-distribution we did household distribution. Once you know where those people are, you go and hand deliver to them and make that close connection. I think that really is what made us stand out, that relation[ship] that we were able to build with them" (Gabi).

The collective effort of the Mayor, Sonje Ayïti, USAID and other locally operating NGOs, activated compassionate empathy among community members. Compassion is empathy in action, 
what others have referred to as sympathetic pity, a concern for and response to other people's sufferings or misfortunes (Dutton et al., 2006; Shepherd \& Williams, 2014). Patrick’s response is indicative of the compassionate empathy we observed: "I felt obliged to give more of my time to Sonje Ayïti. [...] For the ones hurt, we got a colony of doctors to give treatments for them. And this is why we, until to this day, feel good living in our homeland”.

The practice of leadership, assessing needs and advocating roles developed a collective awareness of where to find help, e.g. through trained health advocates, and an externally hired psychologist. Moreover, these practices enhanced community member's understanding of how to distribute the displaced and homeless among families, further activating and increasing collective empathy. Gabi and Steve motivated people, who increasingly felt connected to one another because of their shared concerns. Such convergence in affective responding can be seen in Mayor Manguira comment that "people who had lost everything felt they could rely on people from different organizations again, like in my case [Limonade] there was a Spanish organization, which donated food and we distributed it to 1500 people.”

We thus argue that improvising, assessing needs, leading, and advocating on emergent roles occur as institutional creation practices in the immediate aftermath of a natural disaster. In disaster response, improvising with available resources—showing people how to make makeshift chairs for the school (Vignette I)—creates temporary material solutions. Assessing needs to create a better understanding of the new status-quo, advocating for people to accept emergent roles for organizing, and leading joint recovery efforts supports the implementation of temporary material solutions and further enhances collective awareness. The new material solutions enhance survivors feeling of security, which justifies and sustains current institutional creation work practices: “I keep working with Sonje Ayïti, but not only in order to help other people, but also to secure the wellbeing of my own family” (Jonas). At the same time, a better collective awareness of how to help each other 
activates compassionate empathy, which also motivates a person's future engagement in a new set of practices (compare Phase 1 in Figure 4).

Insert Figure 4 about here

\section{Institutional Creation Work in Post-Disaster Recovery Phase (Fall 2010 - Fall 2012)}

\section{Vignette II: Symbolic Community Solutions Infuse Affective Solidarity in Recovering from a}

Cholera Epidemic. It is October 2011, my second visit to Haiti and I am sat on the dockside looking at a container loaded with materials for building dry toilets destined for Limonade: it's all been stuck there for weeks already. An official is demanding a cut of several thousand US dollars to clear customs despite the container being marked as humanitarian aid, and officially tariff free. It's not surprising that Steve is upset, almost mad with frustration. People are dying of Cholera. A lot of effort has been going into responding to the Cholera outbreak to create awareness and temporary solutions (compare Phase 1 in Figure 4) and now, some corrupt idiot in the port authority was holding back desperately needed supplies. This is Haiti I remind myself. The obvious never happens and when it does, it takes forever. Already months ago, Gabi and Steve had got an ISO to collaborate by designing the centers, and together with villagers had planned where to place the first five to best serve the community. Through that process more and more of the villagers were motivated to volunteer and help: they trusted Gabi and Steve. Everything was ready and waiting.

After further delays we finally get the materials. Someone must have paid the bribe: I don’t ask. The workers are proudly wearing T-shirts with the Sonje Ayïti logo glowing yellow and white in the sun. Gabi and Steve know how to activate Haiti’s culture of solidarity, making workers feeling proud of supporting their community. As it remains difficult to imagine the final look and purpose of the building, Gabi keeps talking about the importance of the toilet centers over and over again. People keep staring at her disbelievingly. She turns to me and says, “in the rural areas some people still don’t believe that Cholera exists and think it is a spell. But because we have been with them for so long, 
they trust us to be able to help them”. She explained to me that it is important to act closely together with the villagers, as it helped repeatedly demonstrate and develop solidarity. The very sight of a team of workers proudly wearing Sonje Ayïti T-shirts slowly convinces villagers to give their approval for their vision to have community toilets to combat Cholera.

Five months later in March 2012, on my third visit I go to see the communal toilet project again. The modern toilet blocks stand taller than the small modest homes in the neighborhood. Carpenters have added ornamental cornices as embellishments. “The people here call it 'chateau caca' [shit castle]. They have become a place for the cool kids to hang out”, Gabi laughs (see Figure 5). We finish admiring the block and walk towards the chicken farm. Gabi reflects sadly on the various reasons why the toilet blocks are not yet open. Building them was one thing, getting the waste disposal system actually working is another. People are still dying of Cholera. The difficulty is finding the money for regular waste removal. Nonetheless, the 'chateau caca' provided the community with a focal point for dealing with Cholera in other ways and provided a vision of how to stop the invisible illness. The toilets are a symbol that give people hope. Something that motivates villagers to find a way to fight the disease. There is even better news elsewhere in the village. The tent-school has been superseded by a semi-permanent brick-school with an improvised roof of battered metal sheets. The locals call it the 'Community School of Hope', an important symbol of post-disaster recovery (see Figure 6), which has motivated the families living nearby to start finding resources to develop an even better school on the adjacent field, so that every local child could go to school (compare Phase 2 in Figure 4).

Insert Figure 5 and 6 about here

Both the toilet centers as well as the 'School of Hope' activated community members' affective solidarity towards one another, which justifies current collaborating, valorizing and reflecting practices. Despite the current lack of feasible, long-term solutions, people nevertheless have trust in 
a shared vision. Witnessing the activities around the toilet centers, the school and the chicken farm, and hearing Steve speak about a vision of improved quality of food, education and sanitation elicited a sense of hope among the people of Limonade. Constant reference to toilet centers and a chicken farm that both remain unopened nevertheless act as symbols for hope in a better future. This hope, though based on incomplete projects, motivates people to engage in further development of these and other initiatives, thereby building everyday institutions.

A Collective Vision Instills Hope Revitalizing Collaborative Initiatives. In the disaster recovery phase, the key institutional creation practices are collaborating with local and international actors that help to create collective trust between local people and engaged post-disaster agents and valorizing symbolic solutions to create a collective vision. We observed the importance of collaborating and valorizing in the aftermath of the cholera outbreak, presented in Vignette II, when the local newspapers and radio stations reported the rise of the Cholera death toll and number of infections on a daily basis (HRRW Blog, 2.11.2010). Being confronted with the reality of Cholera every day, Gabi and Steve activated their diaspora network in the US, who have financed most projects, to search for solutions. While in advanced economies such diseases are easily controlled, inadequate water and sanitation infrastructure in Haiti means that eradicating Cholera is nearly impossible, increasing the need for creating symbolic institutional arrangements such as the 'chateau caca’. In other parts of the country, despite huge donations (Worldvision received \$200 million for Cholera response alone), the official response "is a bitter irony. People die for lack of lifesaving supplies, even though the supplies were right there in front of them” (HRRW Blog, 2.11.2010). For instance, Worldvision withheld 70\% of their Cholera relief equipment for fear of another emergency striking Haiti (HRRW Blog, 2.11.2010). Collaborating with local institutions, NGOs, and foreign business partners was necessary, as Gabi clarified:

"We are currently managing 16 oral dehydration posts, where we got supplies from our partners like UNICEF, like soap, Clorox, Aqua tabs [...] to distribute to the locals. And that helps tremendously. We have been doing some water testing where we discovered most of the water we tested, $98 \%$ of them had e-coli. And now we are trying to mobilize resources so we can provide long term solutions.” 
Sonje Ayïti’s collaboration efforts meant that an ad hoc joint Cholera task force was created with the ISO to build and distribute communal dry-toilets. We observed an inflow of local volunteers with a strong desire to help and to get trained in using and further developing the new toilet infrastructure. The building of the toilet blocks strengthened collective trust in Gabi and Steve, and became symbols of affective solidarity that the community proudly ‘defended' against vandalism. We observed people busying themselves on site demonstrating their solidarity by trying to be useful. One man told me that the project team's ability to bring public toilets to Limonade shows that Gabi can be trusted to know where best to build them so the whole community benefits. This trust and confidence in Steve and Gabi shows affective solidarity justifying ongoing collaborating practices (see Vignette II). Atypically for Haiti, during the construction, building materials were left in the open. No one tried to steal them because the communal solidarity generated by Patrick working together with committed community members protected the materials:

"The community supports me in providing security for the buildings. Because they don't pay a guarding company, and you can’t just leave everything like this! Despite it all, everything has stayed in place, nothing is missing. [...] In other words, people have faith. When Sonje Ayïti has something, they plant it in the community with me.” (Patrick)

Based on community members increased collective trust, Patrick exemplifies the collective practicing of symbolic valorizing of a future vision to instill collective hope. Gabi confirms the importance of valorizing while preparing pasta, Haiti's breakfast of choice, at their restaurant (another social business venture): “The activities we do, it is [about] building future leaders. [...] me, Steve, we get our hands dirty. We don’t just sit there, give orders, do this, do that, because you get paid. I don't get paid, Steve does not get paid... The activities we do, it is building future leaders... I think this is really our model; how we want to inspire hope.” For a visitor coming from a developed economy to the rural community of Limonade, in the poorest country of the Western hemisphere, hearing somebody talking about building future leaders seems rather bizarre. However, valorizing the locals' potential on a daily basis is essential for instilling a feeling of hope. Wances, a fresh high school graduate from Limonade, implicitly acknowledges the significance of Sonje Ayïti valorizing 
a vision for the community to inspire young people, motivating them to be engaged: "In their collaboration with young people and civil society they take up different activities to push young people forward so that the community doesn't stay put, but will advance. [...] I found an opportunity through the Sonje Ayïti Organization to get an education to serve the community. I was very proud of that".

Essential for disaster recovery is how key actors reflect on current practices in order to keep collective trust and vision alive in spite of continuous setbacks. Since solutions in the recovery phase can be rather fleeting and of a symbolic nature (e.g. the withdrawal of ISO as project partner for training workers; the donation for building a university without providing money nor staff to run it), agents experience recurring instances of failure, frustration and need for adjustment. The collective Cholera response collaboration quickly led to five impressive but never opened wooden toilet centers, which still legitimized collaborating and valorizing as essential recovery practices (see Vignette II). Following the stalling of this project Gabi and Steve shifted their collaborating practices towards partnering with local women's cooperatives and American University teams. Likewise, instead of only celebrating the 'chateau caca' as important symbols for change, they shifted their valorizing towards the fixing of wells (the only water supply) and encouraging people to go to the toilet in latrines away from the well. Gabi and Steve arranged regular meetings with community members to listen and get feedback on their initiatives. This usually included inputs from the Mayor and business people in the locality. At one meeting for instance there was a public discussion of various options for generating income to pay for toilet waste removal (such as having a small stand selling soap and toilet paper). These public exchanges provided Steve and Gabi with an opportunity to reflect and adjust their initiatives, but at the same time allowed them to explain to people why these (and other) changes in sanitation practices made sense for the whole community. Dr. Patricia Wolff, CEO of Meds \& Food for Kids, a collaborator in a local rural malnutrition program spoke of the pivotal role of Steve and Gabi’s reflecting practice to develop a collective trust and vision: 
"I mean the organization [Sonje Ayïti] is organized in a smart way because Gabi and Steve are smart. They organized and re-organized, and re-organized, and re-organized, and re-organized, as I have watched them, and I have known Gabi since about 2009, and if it doesn't work they do something else. They don't give up, but they are like watchful and analytical, and if this is not working then they switch to something else.”

Therefore, we argue that collaborating, valorizing, and reflecting are essential institutional creation practices during the temporary recovery process. Weeks after the disaster, most immediate individual needs had been met and the relief efforts shifted towards the community's common goals: designing long-term solutions to further stabilize food, housing and sanitation requires time. The development of collective trust, that then revitalizes affective solidarity to sustain the very same practices, requires collaborating, valorizing and reflecting. "Ultimately what you are doing is just reflecting the deep desire, the collective wish. It is the collective dreams of the people that has been driving me” (Steve). At the same time, the emerging vision and trust cultivate collective hope for a better future (compare Phase 2 in Figure 4). Developing collective hope means that community members start acting on behalf of the community because they share strong feelings of belonging. In other words, collective hope motivates people to start new initiatives, as they have started believing that they will personally recover from the disaster if, and only if, the community as a whole is able to secure education, healthcare, housing and food.

\section{Institutional Creation Work in Post-Disaster Reconstruction Phase (Fall 2012 - Spring 2016)}

Vignette III: Opening a University Restaurant and Farm Spurs Collective Intentions Among

Students and Staff. Wow! I am definitely impressed. In front of me rises a four-story complex, the new public University Roi Henri Christophe, built for USD 30 million with a donation from the Dominican Republic, pledged right after the 2010 earthquake (see Figure 7). It's a sunny morning in January 2016 and together with Vilna, the University Head of International Affairs, we are walking in the fields behind the campus and students are harvesting crops. He proudly explains that before the earthquake Limonade had nothing like this. Educating students from the communities in and around Limonade, he was increasingly aware of the new initiatives that the university will underpin. Vilna 
is certain that it will benefit the whole community. Talking to some of the students I can sense their growing confidence that they are doing something useful and that they are leaving the disaster behind them (see Figure 8). It's my fourth visit, and after many tragic and exasperating experiences where despite the growing hope it was often difficult to be truly optimistic, I feel joy at seeing the students’ passion and the impressive buildings, which look surreally and magnificently out of place compared to other run-down offices and schools in town. Vilna reminds me that it is easy to forget that these achievements are the fruits of collective and persistent efforts. Building a university is one thing, but to make higher education actually work it needed people to be aware of the possibilities and opportunities, and to come together and act intentionally: to make Limonade a university town. When the donation was pledged, it was unclear who would fill the university with life, students, teachers and a curriculum. However, as Vilna explained, it was Sonje Ayïti that helped get a foreign technician to do water testing in the area, to till the field and develop an agriculture curriculum. As he speaks he points towards a little stand in front of the university, explaining that RAFAVAL, the women's cooperative, has started selling cold chocolate drinks which shows the growing collective confidence among the people of Limonade. It reflects villagers being generally more alert, sustaining Vilna’s efforts to further mobilize engagement in the new opportunities for learning: Vilna even tried signing me up as a full-time lecturer!

Insert Figure 7 and 8 about here

Back at 'Under the Tent' (Anba Tonel), as the SAPENSA restaurant in front of the university is called, I learn that the land and restaurant is based on a public-private partnership between the Mayor, one of the farmers' cooperatives and Sonje Ayïti. Steve was keen to mobilize engagement from Haitian Americans to support the provision of hot food as well as practical training and skills development for the students. Gabi contacted several US universities to help develop the curriculum and practical education. Vilna continues that "in one year the university will have the first batch of 1000 students graduating, and they need a place to write their thesis. This could be here [in Anba 
Tonel]”. Jonas, an accountant from Limonade, is enthusiastic at the idea of what the university can foster and feels that students will make use of their skills to start new development initiatives in town. The stories, body postures, laughter and eagerness of Jonas, Vilna and students sitting next to us spoke of their passion for a positive future. Anba Tonel is not just a place to eat but a hive of community innovation, a symbol of hope and solidarity, where people engaged in education experience collective passion. As Gabi explains, even the name celebrates the narrative of the donated tent-school which has become a powerful symbol for disaster recovery (see Vignette 1).

In itself the restaurant with its strongly symbolic name demonstrates the emergence of confidence, justifying current efforts to educate and mobilize engagement in further developing the town. The new collective intentions — between the Mayor, a farmers association and Sonje Ayïti—to start agricultural production alongside the university and selling to the restaurant and elsewhere, have elicited a shared passion particularly among younger community members, motivating new synergistic efforts. For instance, RAFAVAL started selling their products there too, and for the first time in all my visits, students approached me wanting to share their business ideas. Previously they had always spoke hopelessly of looking for mostly non-existent local jobs, or would tell me forlornly about their having to look for work in the Dominican Republic. The confidence and passion that developed in Limonade during the reconstruction phase activated people to start new activities that, at best, would create enduring physical infrastructure, such as the permanent school in the First Section, the university and chicken feed mill (see Phase 3 in Figure 4).

Collective Passion Mobilizes Engagement in Developing a Lasting Physical Infrastructure. A key practice in the disaster reconstruction phase is educating community members to increase collective alertness to exploit opportunities for future community development, resulting in higher confidence among villagers. In addition to large initiatives — the new university (Vignette III)—we found that the community's collective alertness was further strengthened through smaller initiatives, such as student scholarships, teacher training, and mentorship in women groups and cooperatives. 
"Every time students were able to do something and benefit, they never stopped recognizing that it was because of the education Sonje Ayïti had provided for them”, said Wances. Sonje Ayïti also supported RAFAVAL in developing a chocolate processing plant. What Steve calls "being accountable for what you do; have a system in place to track, like we have at the farm”, is an effective approach for educating people. With the help of Sonje Ayïti provided mentors the women's cooperative was able to grow from employing 30 women pre-quake to " 500 women. There are some working in the industrial park, some working in the university, working in the restaurant selling chocolate products, and there are also some in the school. And we collaborate now with Sonje Ayïti to make a bakery in the community” says Ernise, demonstrating their collective confidence in furthering their group’s capacity, justifying and sustaining proceeding with the educating practices. In general, collective confidence explains a shared feeling that people can improve their situation (de Rivera et al., 2007), which in the reconstruction phase legitimizes group members proceeding to pursue a specific project.

Another key practice is mobilizing community engagement in joint reconstruction efforts, which enhances collective intentions towards co-creation of new ideas and solutions, resulting in harmonious passion among alert and engaged community members. In post-disaster reconstruction, alert members captivated by ongoing initiatives was noted in the ethnographer's field diary as illustrating collective passion. For instance, the formal incorporation of interest groups to professionally develop agricultural production and long-term partnerships to improve education activated participation in institutional creation processes. Steve explains the significance of mobilizing regional farmers:

"We are looking at 600 hectares of land being put into use. As for land availability we have close to 45 to 60 thousand hectares of land doing nothing. [...] So, when we are producing we don't want to use full automation. The average number of an efficient number of a Haitian planter per hectare is 14 employees. So, 14 employees multiplied by the average 600 hectares, you see how many people you get employed”. 
Moreover, the chicken processing plant enables many street vendors to connect to local production systems and to sell chicken in smaller portions to a larger customer base. Food-based collaborative behaviors, networks and cooperatives had all but disappeared in recent Haitian history. Therefore, the generation of new street food outlets channels collective passion in the community into new productive activities. Without such positive economic activity, collective alertness, and intentions, constructive passion might dissipate and through unemployment and indolence turn into destructive passion, as the ethnographer vividly experienced during street protests in one of Haiti’s major cities, Cap-Haïtien. In Limonade agents were able to generate communal passion towards long-term societal and institutional change. For example, we sensed the passion of several members, not only towards the university (see Vignette III), but also their enthusiasm for the potential of the new abattoir, with some visiting the construction site on a daily basis, looking for ways to get engaged. Sonson, who works at Anba Tonel, says that Gabi and Steve’s approach:

"gives me pleasure, because a series of things I would not have reached otherwise, I managed to find here. [...] The whole community feels this way, because since the start everyone talks about them, saying that these two people [Gabi and Steve] work like, when they say they do something, they do it. They don’t walk backwards, they just go forward."

Patrick adds that “people in the village have found possibilities, so they don't have to go to Santo Domingo [in neighboring Dominican Republic] to be humiliated, they don't have to go to Santo Domingo to struggle. This is what Sonje Ayïti and SAPENSA have achieved”. Statements like these are a strong indication of the harmonious passion we observed. Harmonious passion refers to an autonomous and free internalization of an activity that is in harmony with other aspects of collective identity (Vallerand et al., 2003). The collective confidence and passion demonstrated in Vignette III helps people to build new social arrangements that supports self-reliance.

Beside educating and mobilizing engagement, we find that synergizing supports the development of enduring physical infrastructure (i.e. institutional capacity) in the disaster reconstruction phase. In Steve's view, synergizing increases production efficiency and improves the supply chain, which is particularly important in the disaster reconstruction process: 


\begin{abstract}
"When we look at production of chicken, in the Haitian context, we look at a population that is underfed, a population that has little access to the basic food necessity, so when producing we look at production first, but we look at how the production really connects to other activities. For example, we're looking at producing 200,000 egg layers, but what you have to take into consideration is the fact that by producing egg layers you have to have access to animal feed, so while we are producing eggs, using egg layers, we will facilitate the regional planters to grow corn”.
\end{abstract}

For this specific effort they founded a chicken farmers association. Patrick recognized the impact of their synergistic approach: "Sonje Ayïti and SAPENSA put their heads together to find resources to create work for 3000-4000 people in husbandry of chicks and industry of packed chicken meat, so that La Cul, Limonade, Cap-Haïtien and the whole north would have work and local production.” By referring back to the newly gained independence from having to look for work abroad and in showing us their produce, all interviewees demonstrated the collective emotions that joint efforts provided. The community’s capacity developed through new enduring material arrangements: increased food production (e.g. vegetable farming and animal husbandry), stronger production chains (e.g. animal feed production, chicken farms, abattoir, retail chain and restaurant), and a permanent education infrastructure (e.g. 'School of Hope', local university).

We have demonstrated that alertness and intentions develop collective confidence, justifying educating and mobilizing engagement practices. Being emotionally alert enhances the collective confidence of feeling able to change the community's situation: "They [Gabi and Steve] have confidence in us and we have confidence in them. [...] To keep partnership functioning, there has to be confidence, there has to be respect on both sides” (Ernise). At the same time these social practices generate passion, motivating people to engage in synergizing practices to create a better physical infrastructure (see Phase 3 in Figure 4). Collective intentions develop community members' harmonious passion to co-create new ideas and solutions for long-term reconstruction. While, in a given context, passion of groups can be harmonious and constructive or obsessive and destructive (Vallerand et al., 2003), recent scholarly work perceives passion to be a consciously accessible, intense feeling that helps groups overcome obstacles through being persistent than they would 
otherwise be (Cardon, Post, \& Forster, 2017). As such, passion motivates people’s engagement in embedding new institutional arrangements.

\section{Collective Emotions Justify and Motivate Institutional Creation Work}

Expanding on our findings, we now describe how collective emotions shape institutional creation work (Figure 9). Situated in a disaster-affected community, our analysis revealed that social practices that create novel institutional arrangements through mobilization of collective emotions both sustain and generate future practices (Battilana \& D’Aunno, 2009; Lawrence \& Dover, 2015; Lawrence \& Suddaby, 2006). We show that, in the disaster response phase, improvising, assessing needs, leading, and advocating on emergent roles are practices that build new institutional arrangements by providing temporary material solutions and building awareness among community members. In the recovery phase, collaborating, valorizing, and reflecting enables the creation of a new collective vision for, and community members' trust in, the future development of their community. In the reconstruction phase, educating, mobilizing engagement, and synergizing generate greater collective alertness and intentions to act, and thereby foster the establishment of permanent physical infrastructure embedded in the community. In each of these phases, we identified a bundle of social practices that generates new institutional arrangements. The new arrangements, in turn, reinforce and sustain these social practices but also enable the emergence of new institution building practices. Our study's key insight is to show the mechanisms of how collective emotions influence institutional creation work processes. This is important because the literature has not yet specified the role of collective emotions in institutional work's central relationship of social practices and institutional arrangements (Moisander et al., 2016; Voronov \& Vince, 2012; Zietsma \& Toubiana, 2018).

Based on the theory of collective emotions, our ethnography demonstrates that institutional creation work practices elicit congruent emotional experiences among people interacting in high physical proximity (von Scheve \& Ismer, 2013). It is known that everyday behavior elicits affective responses that are shaped by the social situations within which they occur (Fan \& Zietsma, 2017; 
Salmela \& Nagatsu, 2016). Our findings show how purposeful institution building converges people’s emotional experiences into collective emotions. As such, collective emotions emerge as a by-product of institution creation work, but at the same time are generative of continued institution building practices. Our research suggest that this is because collective emotions have two primary functions in institutional creation work.

First, we find that key actors' practices creating new institutional arrangements elicit and synchronize collective emotions that in turn help justify the very same practices. As depicted in Figure 9, we reveal that a feeling of security, affective solidarity and collective confidence emerge as collective emotions that legitimize continuing with those institutional creation work practices. In the first phase, we observed Gabi and Steve as key institutional workers who were able to develop a shared feeling of security by creating new awareness and installing temporary material solutions. The heightened sense of security among villagers, in turn, justified continuing with these cognitive and material response practices. In the recovery phase, collective trust and a shared vision unleashed symbolic power to elicit affective solidarity among villagers that, in turn, approved the very same practices of Gabi, Steve, the Mayor and other institutional workers (e.g. valorizing adjusted hygiene behavior, building a few symbolic community toilet centers). Similarly, in the reconstruction phase, the villagers' shared confidence approves sustaining practices that develop collective intentions and collective alertness all in order to eventually create functioning, permanent institutions (see Figure 9). These findings demonstrate that emotions justify the appropriateness of intentional work practices, and thereby collectively approving/disapproving what key actors do (Salmela \& Nagatsu, 2017).

Insert Figure 9 about here

Second, our findings show that the practices that build new institutional arrangements in one phase shape the emergence of new creation work practices in a subsequent phase (Lawrence, Leca, \& Zilber, 2013; Lawrence et al., 2009). Our key insight is that novel institutional arrangements affect 
new practices through eliciting and synchronizing collective emotions that can motivate key actors to engage in new institutional creation work practices (Figure 9). Theorizing from this insight, we suggest collective emotions have an important motivating function (Salmela \& Nagatsu, 2016) in institutional creation work. The main rationale is that synchronized emotional experiences not only justify, legitimize and approve ongoing practices but also provide people with new reasons for action. In the response phase, it was only through new collective awareness (e.g. understanding where internally displaced people were living and how Cholera could be prevented and treated) and the creation of new material solutions (e.g. building the tent school and repurposing a van as a mobile psychological clinic), that people shifted their focus from satisfying personal needs towards the group’s. As a result, in addition to an increased collective approval of Gabi and Steve's ongoing practices, the emergence of shared compassionate empathy motivated villagers to engage with new practices. In the recovery phase, a collective vision for a collaborative food production chain was created which led to the emergence of collective hope among local subsistence farmers and so motivated the mobilization of community engagement through newly founded farmer associations. Likewise, in the reconstruction phase, shared confidence justified collective intentions and alertness that led to the emergence of a passion for self-sufficiency among villagers, encouraging new practices that help embed more permanent institutional infrastructure in the community. Thus, collective emotion motivates individuals to join forces in planning their action, incorporating their own individual plans, but derives reasons for action mainly from the collective emotion itself (Salmela \& Nagatsu, 2016).

In sum, our findings suggest that key actors initiate and drive the creation of disaster-specific, temporary institutional arrangements. As institution building progresses, the disaster becomes less of a reference point and instead key institutional workers increasingly emphasize new embedded routines, realities and physical infrastructure in the community. We witnessed this shift during the second and third phases, when additional agents (e.g. Ernise, Patrick, Vilna) stepped up and joined 
with Gabi and Steve in shaping daily routines. Therefore, we conclude the institution creation process when the efforts of a smaller group of actors to create temporary and symbolic arrangements (e.g. Gabi, Steve, the Mayor) becomes a larger group effort among community actors to more strongly embed new permanent institutions in the community (compare Granqvist \& Gustafsson, 2016; Lawrence, 2017).

\section{DISCUSSION AND IMPLICATIONS}

Our main interest in this ethnographic study was to understand the role of collective emotions in post-disaster institutional work. At the core of institutional work studies is the analysis of social practices that structure daily life (Lawrence \& Suddaby, 2006; Lawrence et al., 2009; Zietsma \& Lawrence, 2010). To conduct such analysis institutional work builds on the typology of creating, maintaining and/or disrupting institutions (Lawrence et al., 2013). Our study expands the institutional creation work perspective by revealing how bundles of social practices mobilize collective emotions through the creation of new institutions in post-disaster settings. Our key theoretical insight is that new institutional arrangements elicit and converge collective emotions which in turn justify and then motivate the creation of new institutional arrangements. Hence, we advance theory on collective emotions in institutional creation work and generate implications for post-disaster management.

\section{Collective Emotions in Institutional Creation Work}

To date, studies on institutional creation work (e.g. Battilana \& D’Aunno, 2009; Lawrence \& Dover, 2015; Zietsma \& McKnight, 2009) stress the emergence of cognitive, symbolic and/or physical institutional arrangements as sequences of collaborative practices forming congruence among multiple actors. Scholars have increasingly recognized that emotions are to a great extent a neglected but defining component of institutional processes (Creed et al., 2014; Fan \& Zietsma, 2017; Grodal \& Granqvist, 2014; Lok et al., 2017; Massa, Helms, Voronov, \& Wang, 2017; Moisander et al., 2016; Voronov, 2014; Voronov \& Vince, 2012; Wright et al., 2017). “Emotions are completely tied up in what it means to be in an institutional setting [...] and what is right to do in an institutional 
setting” (Zietsma \& Toubiana, 2018: 434). Embedded in the theory of collective emotions (Salmela \& Nagatsu, 2016; von Scheve \& Ismer, 2013; von Scheve \& Salmela, 2014), we offer novel evidence to demonstrate how and why collective emotions become constitutive and constituting elements in institutional work processes. Hence, our study expands on the current conceptualizations that seek to move beyond the emotions of individual agents (Lok et al., 2017; Zietsma \& Toubiana, 2018), and moves the focus of shared emotions in institutional creation work from institutional fields (Voronov \& Vince, 2012) and discursive political spaces (Moisander et al., 2016) towards collective emotions in local institutional creation work.

In essence, our analysis reveals how collective emotions not only influence the micro-level practices of institutional workers, but also people's experiences of institutions. We show that institution building elicits and converges collective emotions that in turn support the establishment of embedded institutional arrangements. Here, the theory of collective emotions provides a robust theoretical framework to explain how new institutional arrangements shape people's emotional experiences (Voronov \& Vince, 2012; Zietsma \& Toubiana, 2018): the elicitation and convergence of collective emotions constitutes a certain togetherness both justifying the appropriateness of action and motivating co-agents to engage in joint action (Salmela \& Nagatsu, 2016, 2017; Tuomela, 2013). Specifically, our findings suggest that institutional creation work elicits shared concerns and that the existance of newly created institutions help converge and mobilize people’s affective experiences. Recent studies suggest that emotions affect group-level dynamics, such as jointly agreeing on and enacting shared values (Fan \& Zietsma, 2017; Massa et al., 2017). However, those studies do not acknowledge that emotional experiences can also occur at a group level. This might be because collective emotions are still poorly conceptualized and remain methodologically difficult to capture (von Scheve \& Ismer, 2013). Our study addresses this weakness in the institutional literature by demonstrating a means to understand collective emotions as the elicitation and convergence of affective experiences. 
We highlight that collective emotions fulfil an important justifying function, capturing what is the right thing to do in a certain setting, that is integral to the legitimation of practices creating new institutional arrangements. Institutions become valued beyond their technical usefulness by people’s emotional experiences of and connections to them (Friedland, 2018; Lok et al., 2017). Emotions therefore exercise an important approval function that legitimizes the continuation and further dissemination of current creation work practices. Following the theory of collective emotions, this is because emotions are not just reflexes but also provide people with reasons for engagement (Salmela \& Nagatsu, 2017). These emotive reasons are an integral part of people’s judgement on the appropriateness of specific institution building practices. We thus concur with researchers suggesting that emotions — as embodied, socially constructed knowledge, feeling and ethical reasoning—shape social action underpinning institutions (Friedland, 2018; Massa et al., 2017; Moisander et al., 2016). Following this, we find that a virtuous cycle exists between institutional creation work eliciting collective emotions that sustain practice dissemination creating those institutions in the first place (compare Massa et al., 2017; Voronov \& Vince, 2012).

We also show that newly created institutions mobilize collective emotions that in turn motivate people to engage in new institutional work practices. Echoing the theory of collective emotions, our analysis suggests that through emotional convergence people are motivated to not just approve other's practices, but also join in the practicing and so enable new collective efforts (Salmela \& Nagatsu, 2016, 2017). As such, collective emotions also enable co-engagement in institutional work (Zietsma \& Toubiana, 2018), explaining why new collective engagement in institution building emerges. We find this to be particularly the case when agents’ ongoing practices have received sufficient approval from a group. We propose that approval for ones' practice-i.e. the justifying function of collective emotions - is a precondition for eliciting collective emotions that motivate new action, which we refer to as the motivating function of collective emotions. Our study thus concurs that emotions can enable the connection people feel to a larger group, whose institutionalized norms they espouse 
(Creed et al., 2014; Wright et al., 2017; Zietsma \& Toubiana, 2018). Hence, we suggest that collective emotions serve as a motivating mechanism to spur engagement in embedding those and new institutional arrangements.

Insert Figure 10 about here

At the core of institutional work research is a desire to explain what happens when practices and new institutions become embedded in a place (e.g. Granqvist \& Gustafsson, 2016; Lawrence, 2017; Lawrence \& Dover, 2015). We contribute to an explanation by showing that institutional creation work elicits collective emotions that in turn justify ongoing (at $t_{0}$ ), as well as motivate engagement in new (at $t_{1}$ ), institutional creation work practices, that over time enable embedded institutions to emerge (Figure 10). Emotions, therefore, constitute the institution building process via the justifying and motivating function of collective emotions, providing the glue that binds individuals to larger social groups (Zietsma \& Toubiana, 2018). Moreover, this suggests that collective emotions help create a window of opportunity, via justifying ongoing institutional work practices, and subsequently to construct urgency for embedded institutional arrangements, via motivating joint engagement (Granqvist \& Gustafsson, 2016). Accordingly, collective emotions are essential in driving the process of embedding new institutional arrangements as they create a certain irreversibility and thus enable a community to accept new institutional arrangements and import new practices (Lawrence, 2017). In conclusion, our study moves the focus of emotions in institutional work away from the institutional actor to all the people whose daily reality is intimately tied to the same institutional arrangements; an imporant yet under-examined aspect in institutional work research (Friedland, 2018; Lok et al., 2017; Zietsma \& Toubiana, 2018).

Boundaries and limitations for theoretical generalizations. While rather idiographic in nature, we intended to maximize the relevance for theory on the role of collective emotions in institutional creation work beyond disaster-affected community contexts. Inevitably the endeavor to achieve 
particularity, a key advantage of ethnographies, poses a tradeoff for reaching greater theoretical simplicity and sometimes theoretical generality (Langley, 1999). Our research suggests that collective emotions are constitutive of and constitute the creation of institutional arrangements (Zietsma \& Toubiana, 2018) by demonstrating that collective emotions justify and motivate institution building even years after a major disruption of the setting. Therefore, we argue, our generative model (Figure 10) explains institutional creation work via collective emotions not only in disrupted but also in settings where a major disruption has not been the initial trigger for the application of new institutional work practices.

Based on our study, however, we view physical proximity between actors to be an important boundary condition in explaining how and why collective emotions enable institutional creation work. Central to the theory of collective emotions, the elicitation and convergence of emotions "operate most efficiently when the participants with a shared emotion are physically co-present and jointly attend to the shared object of their emotion” (Salmela and Nagatsu, 2017, 459). At the same time, we suggest actors practicing institutional creation work perceive shared affective responses, and the resulting approval and motivating power, more vividly in local, physically proximate settings than actors focusing on shaping wider institutional fields or discursive political spaces (Moisander et al., 2016; Voronov \& Vince, 2012). Accordingly, we emphasize general applicability of our model in physically-proximate settings, and the focus on local communities (Lawrence \& Dover, 2015) as an important way to further the knowledge of collective emotions in institutional creation work.

Despite these generalizations, we are aware that our focus on the collective nature of affective responding has its limitation. In particular, we examined practices enabling convergence in 'positive’ affective responses among community members and, as a result, under-emphasize practices targeted at the emotional recovery of people (Williams \& Shepherd, 2016). Our emphasis on 'positive' collective emotions limits our implications for understanding the complex interplay with negative, sometimes traumatogenic, collective emotions. Fan and Zietsma (2017) have shown that 'negative' 
social emotions reduce a group's emotional energy with detrimental effects on workers agency in shaping new logic construction and maintenance. Hence, further research is needed that helps develop knowledge of the 'negative' collective emotions and interplay of discrete emotions, for instance hope and despair, affecting and being shaped by institutional work in post-disaster settings.

Moreover, we call for further research on community agents purposefully creating emotions. In our study, we have not been able to illustrate a strategic perspective, where institutional workers intend to elicit certain emotions as a tool to affect others (Lok et al., 2017), as for instance coined in the concept of emotion work (Hochschild, 1979; Zapf, 2002). It would be interesting to better understand how differences in people's emotional investments in an institutional order (Voronov \& Vince, 2012), emotional competence (Voronov \& Weber, 2016) and agentic orientation in shaping emotions (Zietsma \& Toubiana, 2018) complements the identified functions of collective emotions in institutional creation work. At the same time, it could be useful to intertwine a strategic, peoplecentered and structuralist institutional perspective of emotions (Lok et al., 2017) if the aim is to develop a more detailed picture of how certain institutions shape particular collective emotions, and how certain collective emotions shaped particular institutions.

\section{Institutional Work as Post-Disaster Management Practice}

We extend the knowledge of post-disaster management (Drabek \& McEntire, 2003; Quarantelli, 2005; Williams \& Shepherd, 2016) by showing that a community's response to long-term development requires locally embedded institutional work practices that mobilize collective emotions that can help in shifting the community focus from despair to hope. We show that, through mobilizing collective emotions, community members are not only able to (re-)build enduring physical community infrastructure, but also to develop new awareness, and trusting relationships which can foster collective engagement in bettering the community. Following this, our study suggests that stronger collaboration with local actors in post-disaster management is needed, since they possess the requisite long-term interest in community recovery and have the means to build trust and emotional 
connections. In our field work it became evident that well-resourced international actors, capable of responding well to pressing emergency needs, lost local support and sometimes abandoned project plans, because they were not sufficiently attached to the local community (Bell, 2013; Katz, 2013; Schuller, 2012). Compare this to the positive effects of locally embedded and connected actors and activity even when the initiatives were flawed and incomplete.

Similarly, while incoming actors can show strong altruistic motives and have the potential to compensate for potential inefficiencies in state responses, their support is often not well prepared for addressing local needs (Drabek \& McEntire, 2003; Shepherd \& Williams, 2014; Williams \& Shepherd, 2016). In Haiti, for instance, Cholera was reintroduced to the country during the UN mission (Cravioto, Lanata, Latagne, \& Nair, 2010) and prolonged distribution of free food aid undermined Haitian farming resilience (Versluis, 2014). The fact that $80-90 \%$ of incoming international organizations left within 12 months of the earthquake signals a lack of long-term orientation desperately needed in post-disaster rebuilding. This requires making more resources available and better integrating local organizations in disaster rebuilding schemes. In Haiti, local nongovernmental organizations, such as Sonje Ayïti, altogether received less than $1 \%$ of the available relevant funding (United Nations, 2011). Despite an increased risk of nepotism and corruption (which anyway can be mitigated through close collaboration and compliance controls), we recommend international actors and policy-makers encourage partnerships and channel long-term resources beyond the usual government institutions and large international organizations. In order to develop a more resilient support infrastructure (Williams \& Shepherd, 2016), our study suggests that these local organizations are worthy of increased resources as they are able to develop trustworthy ties with their community, and act as legitimate role models.

In particular, we argue physical proximity between support agents and people with immediate personal needs is required to encourage the emergence of hope. This is because support agents need to act resourcefully with what is available and to generate emotional dynamics that dis-embed local 
actors (Ruebottom \& Auster, 2017) from the disaster event and embed them with new community practices. In post-disaster recovery processes, this would enable institutional workers to emphasize practice templates that have developed through earlier interactions in particular places. In the second recovery phase it becomes essential to develop collective trust and vision and reproduce shared feelings of solidarity and hope that buys the time needed for designing more sustainable and locally embedded project initiatives. The implication is that by creating symbolic meaning in the transitional recovery phase, local actors manage community action (Hallett, 2010), which enables subsequent practices to support successful post-disaster reconstruction. Therefore, a shift in post-disaster actors' temporal orientation is necessary to foster long-term change (Granqvist \& Gustafsson, 2016), particularly moving from post-disaster practices that activate symbolic community arrangements towards practices that generate project-specific passion among groups. In conclusion, there is a need to complement the dominant focus on the immediate disaster response (Williams \& Shepherd, 2016) with the development of understanding how locally created embedded institutions can further assist post-disaster management in more substantially supporting communities’ long-term recovery.

\section{CONCLUSION}

We have explained how collective emotions enable institution building. We presented an ethnography of Limonade, a Haitian community affected by the 2010 earthquake, and demonstrated that institutional creation work enables and builds on local community members' shared feeling of security and compassionate empathy (relief phase), affective solidarity and hope (recovery phase), as well as confidence and harmonious passion (reconstruction phase). Expanding on these insights, we have described the justifying and motivating function of collective emotions in the development of embedded institutions. Doing so helped us further explain how and why collective emotions are constitutive and constituting elements in institutional creation work. In conclusion, we hope that our work informs current post-disaster management practice and frames further explorations of collective emotions in institutional theory. 


\section{REFERENCES}

Abrahams, D. 2014. The barriers to environmental sustainability in post-disaster settings: a case study of transitional shelter implementation in Haiti. Disasters, 38 Suppl 1: S25-49.

Altay, N., \& Labonte, M. 2014. Challenges in humanitarian information management and exchange: evidence from Haiti. Disasters, 38 Suppl 1(December 2010): S50-72.

Alvesson, M., \& Karreman, D. 2007. Constructing mystery: Empirical matters in theory development. Academy of Management Review, 32(4): 1265-1281.

Bar-Tal, D., Halperin, E., \& de Rivera, J. 2007. Collective emotions in conflict situations: Societal implications. Journal of Social Issues, 63(2): 441-460.

Barley, S. R., \& Tolbert, P. S. 1997. Institutionalization and Structuration: Studying the links between Action and Institution. Organization Studies, 18(1): 93-117.

Battilana, J., \& D’Aunno, T. 2009. Institutional Work and the Paradox of Embedded Agency. In T. B. Lawrence, R. Suddaby, \& B. Leca (Eds.), Institutional Work: Actors and Agency in Institutional Studies of Organizations: 31-58. Cambridge, UK: Cambridge University Press.

Beckert, J. 1999. Agency, Entrepreneurs, and Institutional Change. The Role of Strategic Choice and Institutionalized Practices in Organizations. Organization Studies, 20(5): 777-799.

Bell, B. 2013. Fault Lines: Views Across Haiti's Divide (1st ed.). Ithaca, United States: Cornell University Press.

Biquet, J.-M. 2013. Haiti: Between Emergency and Reconstruction - An inadequate response. International Development Policy| Revue Internationale de Politique de Développement, 4.3: 129-135.

Bornstein, L., Lizarralde, G., Gould, K. A., \& Davidson, C. 2013. Framing responses to post-earthquake Haiti: How representations of disasters, reconstruction and human settlements shape resilience. International Journal of Disaster Resilience in the Built Environment, 4(1): 43-57.

Bourdieu, P. 2000. Pascalian Meditations. Stanford University Press.

Cardon, M. S., Post, C., \& Forster, W. R. 2017. Team entrepreneurial passion (TEP): Its emergence and influence in new venture teams. Academy of Management Review, 42(2): 283-305.

Corbin, J., \& Strauss, A. 2008. Basics of Qualitative Research: Techniques and Procedures for Developing Grounded Theory (3rd ed.). Los Angeles, CA: Sage Publications.

Cravioto, A., Lanata, C. F., Latagne, D. S., \& Nair, G. B. 2010. Final Report of the Independent Panel of Experts on the Cholera Outbreak in Haiti.

Creed, W. E. D., Hudson, B. A., Okhuysen, G. A., \& Smith-Crowe, K. 2014. Swimming in a Sea of Shame: Incorporating Emotion into Explanations of Institutional Reproduction and Change. Academy of Management Review, 39(3): 275-301.

Dacin, M. T., Goodstein, J., \& Scott, W. R. 2002. Institutional Theory and Institutional Change: Introduction to the Special Research Forum. Academy of Management Journal, 45(1): 43-56.

de Rivera, J. 1992. Emotional Climate: Social Structure and Emotional Dynamics. In K. T. Strongman (Ed.), International Review of Studies on Emotion, vol. 2: 197-218. John Wiley \& Sons.

de Rivera, J., Kurrien, R., \& Olsen, N. 2007. Emotional climate of nations and their culture of peace. Journal of Social Issues, 63(2): 255-271.

de Rivera, J., \& Páez, D. 2007. Emotional climate, human security, and cultures of peace. Journal of Social Issues, 63(2): 233-253.

de Rond, M., \& Lok, J. 2016. Some Things Can Never Be Unseen: The Role of Context in Psychological Injury at War. Academy of Management Journal, 59(6): 1965-1993.

Dover, G., \& Lawrence, T. B. 2010. A Gap Year for Institutional Theory: Integrating the Study of Institutional Work and Participatory Action Research. Journal of Management Inquiry, 19(4): 305-316.

Down, S., \& Reveley, J. 2009. Between narration and interaction: Situating first-line supervisor identity work. Human Relations, 62(3): 379-401.

Drabek, T. E., \& McEntire, D. A. 2003. Emergent phenomena and the sociology of disaster: lessons, trends and opportunities from the research literature. Disaster Prevention and Management, 12(2): 97-112.

Dutton, J. E., Worline, M. C., Frost, P. J., \& Lilius, J. 2006. Explaining Compassion Organizing. Administrative Science Quarterly, 51: 59-96.

Eisenhardt, K. M., Graebner, M. E., \& Sonensheim, S. 2016. From the Editors: Grand Challenges and Inductive Methods: Rigor Without Rigor Mortis. Academy of Management Journal, 59(4): 1113-1123.

Emirbayer, M., \& Goldberg, C. A. 2005. Pragmatism, Bourdieu, and collective emotions in contentious politics. Theory and Society, 34: 469-518.

Fan, G. H., \& Zietsma, C. 2017. Constructing a Shared Governance Logic: The Role of Emotions in Enabling Dually Embedded Agency. Academy of Management Journal, 60(6): 2321-2351.

Fredrickson, B. L., Tugade, M. M., Waugh, C. E., \& Larkin, G. R. 2003. What Good are Positive Emotions in crisies? A Prospective Study of Resilience and Emotions Following the Terrorist Attacks on the United States on September 11th, 2001. Journal of Personality and Social Psychology, 84(2): 365-376. 
Friedland, R. 2018. Moving Institutional Logics Forward: Emotion and Meaningful Material Practice. Organization Studies, 39(4): 515-542.

Geertz, C. 1972. Deep Play: Notes on the Balinese Cockfight. Daedalus, 101(1): 1-37.

Gieryn, T. F. 2000. A Space for Place in Sociology. Annual Review of Sociology, 26(1): 463-496.

Granqvist, N., \& Gustafsson, R. 2016. Temporal Institutional Work. Academy of Management Journal, 59(3): 10091035.

Grodal, S., \& Granqvist, N. 2014. Great Expectations: Discourse and Affect during Field Emergence. Emotions and the Organizational Fabric, Research on Emotion in Organizations, 10: 139-166.

Hallett, T. 2010. The Myth Incarnate: Recoupling Processes, Turmoil, and Inhabited Institutions in an Urban Elementary School. American Sociological Review, 75(1): 52-74.

Hällgren, M., Rouleau, L., \& de Rond, M. 2018. A Matter of Life or Death: How Extreme Context Research Matters for Management and Organization Studies. Academy of Management Annals, 12(1): 111-153.

Halperin, E. 2014. Collective Emotions and Emotion Regulation in Intractable Conflicts. In C. von Scheve \& M. Salmela (Eds.), Collective Emotions: Perspectives from Psychology, Philosophy, and Sociology: 281-295. Oxford: Oxford University Press.

Hochschild, A. R. 1979. Emotion Work, Feeling Rules, and Social Structure. American Journal of Sociology, 85(3): 551-575.

IHSI. 2009. Population Totale, Population de 18 Ans et Plus Menages et Densites Estimées en 2009. Port-au-Prince: Institut Haïtien de Statistique et d'Informatique.

IHSI. 2015. Population Totale, Population de 18 Ans et Plus Menages et Densites Estimées en 2015. Port-au-Prince: Institut Haïtien de Statistique et d'Informatique.

Jasper, J. M. 2011. Emotions and Social Movements: Twenty Years of Theory and Research. Annual Review of Sociology, 37: 285-303.

Kaplan, S., \& Orlikowski, W. J. 2013. Temporal work in strategy making. Organization Science, 24(4): $965-995$.

Kates, R. W., Colten, C. E., Laska, S., \& Leatherman, S. P. 2006. Reconstruction of New Orleans after Hurricane Katrina: a research perspective. Proceedings of the National Academy of Sciences of the United States of America, 103(40): 14653-60.

Katz, J. M. 2013. The Big Truck That Went By: How the World Came to Save Haiti and Left Behind a Disaster. New York: Palgrave Macmillan.

Langley, A. 1999. Strategies for theorizing from process data. Academy of Management Review, 24(4): 691-710.

Langley, A., Smallman, C., Tsoukas, H., \& Van de Ven, A. H. 2013. Process Studies Of Change In Organization And Management: Unveiling Temporality, Activity, And Flow. Academy of Management Journal, 56(1): 1-13.

Lawrence, T. B. 2017. High-Stakes Institutional Translation: Establishing North America's First GovernmentSanctioned Supervised Injection Site. Academy of Management Journal, 60(5): 1771-1800.

Lawrence, T. B., \& Dover, G. 2015. Place and Institutional Work: Creating Housing for the Hard-to-house. Administrative Science Quarterly, 60(3): 371-410.

Lawrence, T. B., Leca, B., \& Zilber, T. B. 2013. Institutional Work: Current Research, New Directions and Overlooked Issues. Organization Studies, 34(8): 1023-1033.

Lawrence, T. B., \& Suddaby, R. 2006. 1.6 Institutions and Institutional Work. In S. Clegg, C. Hardy, T. B. Lawrence, \& W. R. Nord (Eds.), The SAGE Handbook of Organization Studies: 215-254. Thousand Oaks, CA: SAGE.

Lawrence, T. B., Suddaby, R., \& Leca, B. 2009. Institutional Work: Actors and Agency in Institutional Studies of Organizations. Cambridge: Cambridge University Press.

Lawrence, T. B., Suddaby, R., \& Leca, B. 2011. Institutional Work: Refocusing Institutional Studies of Organization. Journal of Management Inquiry, 20(1): 52-58.

Lizarralde, G., Johnson, C., \& Davidson, C. 2010. Rebuilding After Disasters: From Emergency to Sustainability. New York: Spon Press.

Locke, K., \& Golden-Biddle, K. 1997. Constructing Opportunities For Contribution: Structuring Intertextual Coherence And “Problematizing” In Organizational Studies. Academy of Management Journal, 40(5): 1023-1062.

Lok, J., Creed, W. E. D., DeJordy, R., \& Voronov, M. 2017. Living Institutions: Bringing Emotions into Organizational Institutionalism. In T. L. \& R. M. R. Greenwood, C. Oliver (Ed.), The SAGE Handbook of Organizational Institutionalism (2nd ed.). Thousand Oaks, CA: Sa.

Lok, J., \& de Rond, M. 2012. On the Plasticity of Institutions: Containing and Restoring Practice Breakdowns at the Cambridge University Boat Club. Academy of Management Journal, 56(1): 185-207.

Majchrzak, A., Jarvenpaa, S. L., \& Hollingshead, A. B. 2007. Coordinating Expertise Among Emergent Groups Responding to Disasters. Organization Science, 18(1): 147-161.

Mantere, S., \& Ketokivi, M. 2013. Reasoning in organization science. Academy of Management Review, 38(1): 70-89.

Marquis, C., Glynn, M. A., \& Davis, G. F. 2007. Community Isophomorphism and Corporate Social Action. Academy of Management Review, 32(3): 925-945.

Massa, F. G., Helms, W., Voronov, M., \& Wang, L. 2017. Emotions Uncorked: Inspiring Evangelism for the Emerging Practice of Cool Climate Winemaking in Ontario. Academy of Management Journal, 60(2): 461-499. 
Moisander, J. K., Hirsto, H., \& Fahy, K. M. 2016. Emotions in Institutional Work: A Discursive Perspective. Organization Studies, 37(7): 963-990.

Norris, F. H., Friedman, M. J., \& Watson, P. J. 2002. 60,000 disaster victims speak: Part II. Summary and implications of the disaster mental health research. Psychiatry, 65(3): 240-260.

Pacherie, E. 2014. How does it feel to act together? Phenomenology and the Cognitive Sciences, 13(1): 25-46.

Paton, D. 2006. Disaster resilience: integrating individual, community, institutional and environmental perspectives. In D. Paton \& D. Johnston (Eds.), Disaster resilience: An integrated approach: 305-318. Springfield, Illinois: Charles C Thomas Publisher.

Perry, R. W. 2009. What is a disaster? In H. Rodriguez, E. L. Quarantelli, \& R. R. Dynes (Eds.), Handbook of Disaster Research: 1-15. New York, USA: Springer Science+Business Media.

Quarantelli, E. 2005. What is a disaster?: perspectives on the question. New York: Routledge. http://www.google.com/books?hl=en\&lr=\&id=WLT9K1bSqWYC\&oi=fnd\&pg=PR9\&ots=hRQGopQbAp\&sig= Hhdw5-ugK0-XUkj3YIPbXFVjB2c.

Ruebottom, T., \& Auster, E. R. 2017. Reflexive dis/embedding: Personal narratives, empowerment and the emotional dynamics of interstitial events. Organization Studies. https://doi.org/10.1177/0170840617709308.

Salmela, M., \& Nagatsu, M. 2016. Collective Emotions and Joint Action. Journal of Social Ontology, 2(1): 33-57.

Salmela, M., \& Nagatsu, M. 2017. How does it really feel to act together? Shared emotions and the phenomenology of we-agency. Phenomenology and the Cognitive Sciences, 16(3): 449-470.

Schatzki, T. R. 2005. Peripheral Vision: The Sites of Organizations. Organization Studies, 26(3): $465-484$.

Schuller, M. 2012. Killing with Kindness: Haiti, International Aid, and NGOs. New Brunswick: Rutgers University Press.

Scott, W. R. 2014. Institutions and organizations: ideas, interests, and identities (4th ed.). Thousand Oaks, CA: Sage.

Seo, M.-G., \& Creed, W. E. D. 2002. Institutional Contradictions, Praxis, and Institutional Change: A Dialectical Perspective. Academy of Management Review, 27(2): 222-247.

Shepherd, D. A., \& Williams, T. A. 2014. Local Venturing As Compassion Organizing In The Aftermath Of A Natural Disaster: The Role Of Localness And Community In Reducing Suffering. Journal of Management Studies, 51(6): 952-994.

Shin, J., Taylor, M. S., \& Seo, M. G. 2012. Resources for Change: The relationships of organizational inducements and psychological resilience to employees' attitudes and behaviors toward organizational change. Academy of Management Journal, 55(3): 727-748.

Smets, M., Jarzabkowski, P., Burke, G. T., \& Spee, P. 2015. Reinsurance Trading in Lloyd'S of London: Balancing Conflicting-Yet-Complementary Logics in Practice. Academy of Management Journal, 58(3): 932-970.

Sneath, J. Z., Lacey, R., \& Kennett-Hensel, P. A. 2009. Coping with a natural disaster: Losses, emotions, and impulsive and compulsive buying. Marketing Letters, 20(1): 45-60.

Stigliani, I., \& Ravasi, D. 2012. Organizing Thoughts and Connecting Brains: Material Practices and the Transition From Individual To Group-Level Prospective Sensemaking. Academy of Management Journal, 55(5): 12321259.

Tuomela, R. 2013. Social Ontology. New York: Oxford University Press.

Turner, J. H. 2009. The Sociology of Emotions: Basic Theoretical Arguments. Emotion Review, 1(4): 340-354.

United Nations. 2011. Has Aid Changed? Channelling assistance to Haiti before and after the earthquake. New York, USA.

Vaara, E., \& Whittington, R. 2012. Strategy-as-Practice: Taking Social Practices Seriously. The Academy of Management Annals, 6(1): 285-336.

Vallerand, R. J., Blanchard, C., Mageau, G. A., Koestner, R., Ratelle, C., et al. 2003. Les Passions de l’âme: On Obsessive and Harmonious Passion. Journal of Personality and Social Psychology, 85(4): 756-767.

Van Maanen, J. 2011. Tales of the Field: On Writing Ethnography. Chicago: University of Chicago Press.

Vázquez, C., Cervellón, P., Pérez-Sales, P., Vidales, D., \& Gaborit, M. 2005. Positive emotions in earthquake survivors in El Salvador (2001). Journal of Anxiety Disorders, 19(3): 313-328.

Versluis, A. 2014. Formal and informal material aid following the 2010 Haiti earthquake as reported by camp dwellers. Disasters, 38 Suppl 1: S94-109.

von Scheve, C., \& Ismer, S. 2013. Towards a Theory of Collective Emotions. Emotion Review, 5(4): $406-413$.

von Scheve, C., \& Salmela, M. 2014. Collective Emotions. Oxford, UK: Oxford University Press.

Voronov, M. 2014. Towards a Toolkit for Emotionalizing Insitutional Theory. In N. M. Ashkanasy, W. J. Zerbe, \& C. E. J. Hätel (Eds.), Research on Emotion in Organizations, vol. 10: 167-196. Emerald Group Publishing Limited.

Voronov, M., \& Vince, R. 2012. Integrating Emotions into the Analysis of Institutional Work. Academy of Management Review, 37(1): 58-81.

Voronov, M., \& Weber, K. 2016. The heart of institutions : Emotional competence and institutional actorhood. Academy of Management Review, 41(3): 456-478.

Walker, S. 2011. Al Jazeera Correspondent - Haiti: After the Quake. Al Jazeera.

Williams, T. A., \& Shepherd, D. A. 2016. Building Resilience or Providing Sustenance: Different Paths of Emergent 
Ventures in the Aftermath of the Haiti Earthquake. Academy of Management Journal, 59(6): $2069-2102$.

Wright, A. L., Zammuto, R. F., \& Liesch, P. W. 2017. Maintaining the Values of a Profession: Institutional Work and Moral Emotions in the Emergency Department. Academy of Management Journal, 60(1): 200-237.

Zanotti, L. 2010. Cacophonies of Aid, Failed State Building and NGOs in Haiti: setting the stage for disaster, envisioning the future. Third World Quarterly, 31(5): 755-771.

Zapf, D. 2002. Emotion work and psychological well-being. A review of the literature and some conceptual considerations. Human Resource Management Review, 12(2): 237-268.

Zietsma, C., Groenewegen, P., Logue, D., \& Hinings, C. 2017. Field or fields? Building the scaffolding for cumulation of research on institutional fields. The Academy of Management Annals, 11(1): 391-450.

Zietsma, C., \& Lawrence, T. B. 2010. Institutional Work in the Transformation of an Organizational Field: The Work and Practice Work. Administrative Science Quarterly, 55: 189-221.

Zietsma, C., \& McKnight, B. 2009. Building the Iron Cage: Institutional Creation Work in the Context of Competing Proto-institutions. In T. B. Lawrence, R. Suddaby, \& B. Leca (Eds.), Institutional Work: Actors and Agency in Institutional Studies of Organizations: 143-177. Cambridge, UK: Cambridge University Press.

Zietsma, C., \& Toubiana, M. 2018. The Valuable, the Constitutive, and the Energetic: Exploring the impact and importance of studying emotions and institutions. Organization Studies, 39(4): 427-443. 
TABLES AND FIGURES

Figure 1. Evidence of missing templates for organizing in Haiti after the earthquake Jan. 2010

\begin{tabular}{|c|c|c|c|}
\hline $\begin{array}{l}\text { MAIN POST- } \\
\text { DISASTER NEED }\end{array}$ & $\begin{array}{l}\text { EMERGENCY RESPONSE } \\
\text { Lifesaving (Search and rescue, } \\
\text { medical aid, basic needs) }\end{array}$ & Basic Facilities (food, health, shelter) & $\begin{array}{l}\text { RECONSTRUCTION } \\
\text { Infrastructure and livelihoods; education; } \\
\text { future preparedness }\end{array}$ \\
\hline $\begin{array}{l}\text { SOURCES OF } \\
\text { INSTITUTIONAL } \\
\text { FAILURE IN } \\
\text { HAITI AFTER } \\
\text { THE JAN. 12, } 2010 \\
\text { EARTHQUAKE }\end{array}$ & $\begin{array}{l}>\text { Physical collapse of } 31 \text { government } \\
\text { offices makes the Haitian administration } \\
\text { unresponsive } \\
>\text { Inflow of foreign aid worker creates } \\
\text { coordination problems } \\
>\text { Response Clusters communicated in } \\
\text { English, thereby excluding most Haitian } \\
\text { Actors } \\
>\text { dependency on foreign aid: "the Haitian } \\
\text { government has only received } 49,198 \text { of the } \\
200,000 \text { tents it has requested from the } \\
\text { international community, and only } 15,000 \\
\text { of these tents are available in Haiti as of } \\
\text { today." (HRRW, } 12.02 .2010 \text { ) }\end{array}$ & $\begin{array}{l}\text { > Initially several hundred-thousand Haitians looked } \\
\text { for shelter in tent camps. Later a rumor started to } \\
\text { spread that all camp citizens will be given a house, } \\
\text { causing a further inflow of Haitians to a point where } \\
1.5 \text { million lived in tent cities } \\
\text { > slow removal of debris } \\
>\text { clash of local versus external practices (parallel } \\
\text { system of governance vs. 'NGO-state') } \\
\text { > Nepalese soldiers of the UN peacekeeping mission } \\
\text { brought cholera to Haiti. A leakage in the UN camp in } \\
\text { Artibonite spread the bacterium into a local river, and } \\
\text { caused a chain of more than } 700 \text { 000 infected citizens } \\
\text { (approx. } 14 \% \text { of total population) }\end{array}$ & $\begin{array}{l}\text { > "A new analysis by the UN Special Envoy for Haiti } \\
\text { shows that just } 37 \text { percent of the } \$ 4.6 \text { billion in funding } \\
\text { pledged at the donor conference one year ago has been } \\
\text { disbursed" (HRRW, 08.04.2011) } \\
>\text { Temporary shelter became permanent: "Between } \\
\text { June } 2010 \text { and March } 2011 \text { over } 230,000 \text { people were } \\
\text { evicted" (HRRW, } 12.01 .2012 \text { ) and an IOM study } \\
\text { reports that only seven percent received assistance } \\
\text { (HRRW, } 10.01 .2012 \text { ). } \\
\text { > In an official letter Haitian officials complain: "The } \\
\text { twelve Haitian members present here feel completely } \\
\text { disconnected from the activities of the IHRC." The } \\
\text { IHRC is the multi-donor trust fund, administering trans- } \\
\text { governmental aid money (HRRW, 08.04.2011) }\end{array}$ \\
\hline $\begin{array}{l}\text { EXAMPLES OF } \\
\text { MISSING } \\
\text { INSTITUTIONAL } \\
\text { TEMPLATES FOR } \\
\text { POST-DISASTER } \\
\text { ORGANIZING } \\
\text { (REPORTED BY } \\
\text { THE MEDIA) }\end{array}$ & $\begin{array}{l}\text { Regarding the UN mission: "Haitians know } \\
\text { that's the way they act with us. They treat us } \\
\text { like animals," said Lourette Elris, as she } \\
\text { divided the rice amongst the women. "They } \\
\text { gave us the food, we were on our way home, } \\
\text { then the troops threw tear gas at us. We } \\
\text { finished receiving the food, we weren't } \\
\text { disorderly." (Herz, 30.03.2010, IPS News) } \\
\text { "We only found out for folks in our } \\
\text { community that it was a red zone because } \\
\text { we weren't getting any help. That green, } \\
\text { yellow, and red zoning actually comes from } \\
\text { maps when there's war, but there's no war } \\
\text { here in Haiti." Regine Zamor, a Haitian- } \\
\text { American (Herz, 30.03.2010, IPS News) }\end{array}$ & $\begin{array}{l}\text { World Vision, whose donate to Haiti webpage says, } \\
\text { "Your gift will help us meet the immediate, urgent } \\
\text { needs of earthquake survivors, and also enable World } \\
\text { Vision to help the people of Haiti rebuild and recover } \\
\text { in the weeks and months to come," had spent less than } \\
30 \% \text { of the near } \$ 200 \text { millions in cholera supplies in } \\
\text { Port-au-Prince. The excuse: "If we send everything we } \\
\text { have here today, tomorrow we cannot answer for the } \\
800,000 \text { cases". This is a common refrain: money must } \\
\text { be saved for future emergencies, while over a million } \\
\text { people live through an emergency each and every day. } \\
\text { (HRRW, 02.11.2010) } \\
\text { On Monday March 12th, 2012, the tents of Camp } \\
\text { Lycèe Toussaint in downtown Port-au-Prince became } \\
\text { engulfed in flames. Within an hour, 96 of the } \\
\text { approximately } 120 \text { emergency shelters burned to the } \\
\text { ground. Although most of the camp residents escaped } \\
\text { without serious injury, the families lost the few } \\
\text { belongings they had accumulated in the two years and } \\
\text { two months since the earthquake. Camp residents } \\
\text { reported that they did not have water to extinguish the } \\
\text { fire. For months, five Red Cross water tanks have sat } \\
\text { empty at the entrance to the camp [...] Residents said } \\
\text { that IOM staff came to the camp for "only some } \\
\text { minutes" and added that they "told us nothing" [...] } \\
\text { Camp residents commented that their entire camp can } \\
\text { burn along with their children, and the Haitian } \\
\text { Government does nothing. (HRRW, } 14.03 .2012 \text { ) }\end{array}$ & $\begin{array}{l}\text { Documentary Film (Haiti: Where did the money go?) } \\
\text { maker Michele Mitchell explains: "The thing is, I went } \\
\text { to Haiti twice ten months after the earthquake to see } \\
\text { what was happening, and then at the } 20 \text {-month mark, } \\
\text { and we have pictures... the camp situation had } \\
\text { deteriorated. There were camps of } 5,000 \text { people with six } \\
\text { toilets between them. There were millions of people in } \\
\text { tents during the hurricane, and they were terrified. I like } \\
\text { happy endings, and I wish I could report that 'disaster } \\
\text { relief } 2.0 \text { ' had worked, but the picture tells a different } \\
\text { story." (Huffington Post, 25.01.2012) } \\
\text { "The Red Cross' initial plan said the focus would be } \\
\text { building homes - an internal proposal put the number } \\
\text { at } 700 \text {. Each would have finished floors, toilets, } \\
\text { showers, even rainwater collection systems. The houses } \\
\text { were supposed to be finished in January 2013. None of } \\
\text { that ever happened. Carline Noailles, who was the } \\
\text { project's manager in Washington, said it was endlessly } \\
\text { delayed because the Red Cross 'didn't have the know- } \\
\text { how." (PBS, 03.06.2015) } \\
\text { In response to a } 24 \text { million USD project by the Red } \\
\text { Cross, two local citizens report on their experience: } \\
\text { Julnet says "I don't understand an organization like the } \\
\text { Red Cross acting like that. If they have received that } \\
\text { kind of money, maybe they paid their employees with } \\
\text { it? That is OK. But that kind of money spent here in the } \\
\text { community? No, that cannot be said (NPR 03.06. 2015) }\end{array}$ \\
\hline
\end{tabular}

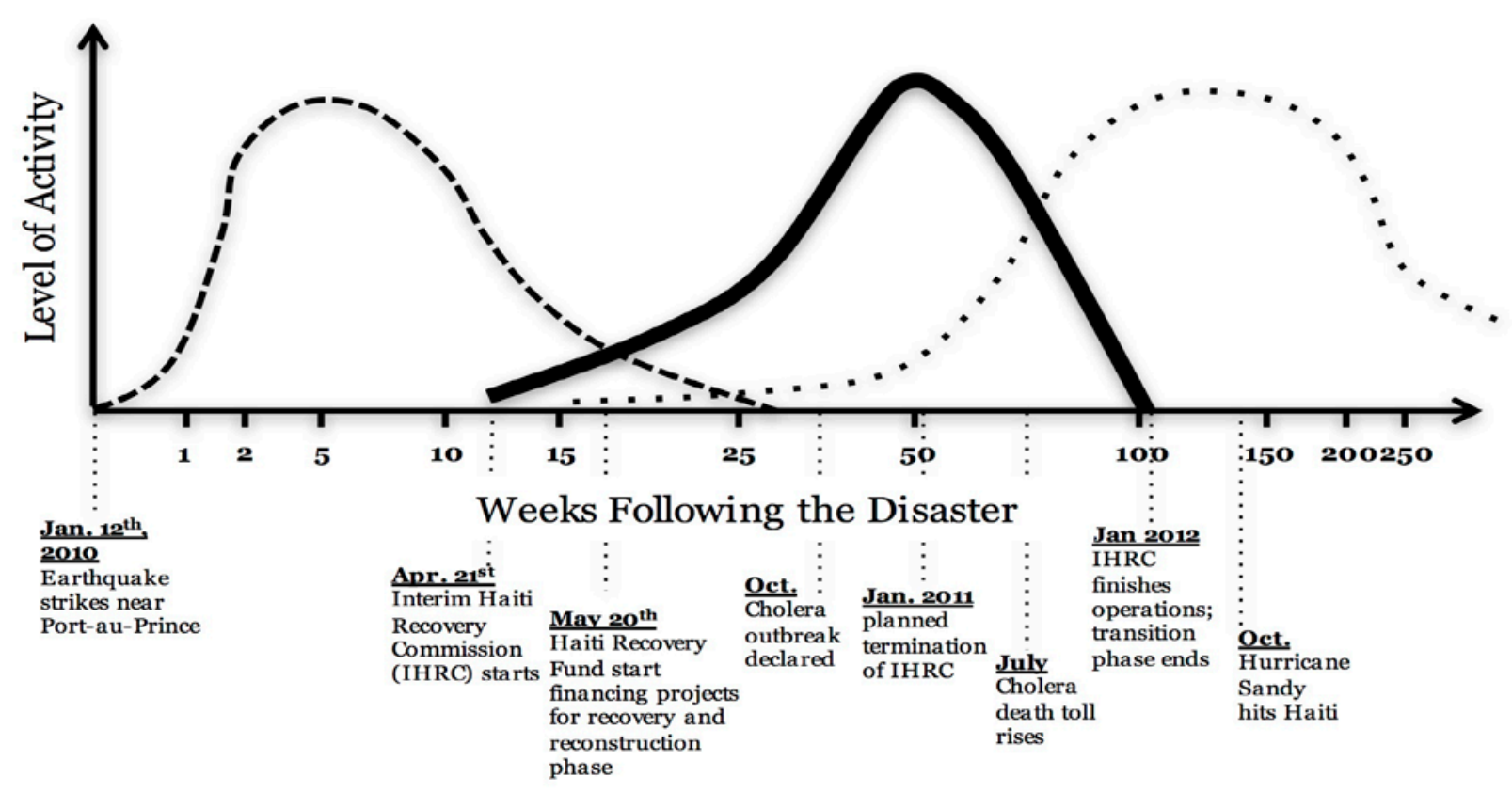


Table 1. Overview of data collection process

\begin{tabular}{|c|c|c|c|c|}
\hline & $\begin{array}{c}\text { Phase 1 } \\
\text { 2010-Jun } 2011\end{array}$ & $\begin{array}{c}\text { Phase } 2 \\
\text { Jul-Dec } 2011\end{array}$ & $\begin{array}{c}\text { Phase } 3 \\
2012\end{array}$ & $\begin{array}{c}\text { Phase } 4 \\
\text { 2013-2016 }\end{array}$ \\
\hline $\begin{array}{l}\text { Participant } \\
\text { Observation }\end{array}$ & $\begin{array}{l}8 \text { days } \\
\text { (April 2011) }\end{array}$ & $\begin{array}{l}10 \text { days } \\
\text { (Oct 2011) }\end{array}$ & $\begin{array}{l}11 \text { days }+4 \text { days } \\
\text { (Mar-Apr 2012) }\end{array}$ & $\begin{array}{l}8 \text { days } \\
(\text { Jan 2016) }\end{array}$ \\
\hline Interviews & 18 & 7 & 12 & 16 \\
\hline $\begin{array}{l}\text { Secondary Data: } \\
\text { Media Articles }\end{array}$ & $\begin{array}{l}710 \text { pages } \\
\text { (292 articles) }\end{array}$ & $\begin{array}{l}129 \text { pages } \\
\text { (37 articles) }\end{array}$ & $\begin{array}{l}228 \text { pages } \\
\text { (74 articles) }\end{array}$ & $\begin{array}{l}315 \text { pages } \\
\text { (106 stories) }\end{array}$ \\
\hline Analytical Focus & $\begin{array}{l}\text { Activities of } \\
\text { various post- } \\
\text { disaster actors }\end{array}$ & $\begin{array}{l}\text { Returnee } \\
\text { entrepreneurs' } \\
\text { practices }\end{array}$ & $\begin{array}{l}\text { Personal } \\
\text { experience of } \\
\text { returnees' } \\
\text { institutional work }\end{array}$ & $\begin{array}{l}\text { New social } \\
\text { arrangements that } \\
\text { have been } \\
\text { institutionalized }\end{array}$ \\
\hline Research Task & $\begin{array}{l}\text { Acculturation, } \\
\text { Identification of } \\
\text { key parties, } \\
\text { Trust-building }\end{array}$ & $\begin{array}{l}\text { Understanding of } \\
\text { practices, } \\
\text { Development of } \\
\text { analytical } \\
\text { framework } \\
\text { (theoretical focus } \\
\text { emerges) }\end{array}$ & $\begin{array}{l}\text { Empathetic } \\
\text { understanding } \\
\text { (inside view) }\end{array}$ & $\begin{array}{l}\text { Critical reflection } \\
\text { on previous } \\
\text { findings, more } \\
\text { fine-grained } \\
\text { perspective } \\
\text { (critical view) }\end{array}$ \\
\hline Researcher Status & $\begin{array}{l}\text { 'Outsider', } \\
\text { observer, us vs. } \\
\text { them segregation }\end{array}$ & $\begin{array}{l}\text { 'Evolving } \\
\text { Insider', } \\
\text { perceived as a } \\
\text { partner }\end{array}$ & $\begin{array}{l}\text { 'Insider', accepted } \\
\text { member with a } \\
\text { shared cause }\end{array}$ & $\begin{array}{l}\text { 'Challenger', } \\
\text { evaluating } \\
\text { practices and } \\
\text { results }\end{array}$ \\
\hline $\begin{array}{l}\text { Researcher } \\
\text { Emotions }\end{array}$ & $\begin{array}{l}\text { Discomfort with } \\
\text { poverty level, } \\
\text { excitement for } \\
\text { post-shock relief } \\
\text { efforts, emphasis } \\
\text { on } \\
\text { personal/cultural } \\
\text { differences }\end{array}$ & $\begin{array}{l}\text { Sympathy for } \\
\text { local community, } \\
\text { critical } \\
\text { perspective on } \\
\text { non-Haitian } \\
\text { engagement, } \\
\text { emphasis on } \\
\text { commonalities }\end{array}$ & $\begin{array}{l}\text { Appreciated } \\
\text { associate of the } \\
\text { wider team, } \\
\text { personal bond } \\
\text { with community } \\
\text { members }\end{array}$ & $\begin{array}{l}\text { Feelings of } \\
\text { 'returning home', } \\
\text { warmly } \\
\text { welcomed, } \\
\text { entrusted with } \\
\text { personal } \\
\text { information }\end{array}$ \\
\hline
\end{tabular}

Table 2a. Illustrative examples for new institutional arrangements in Limonade

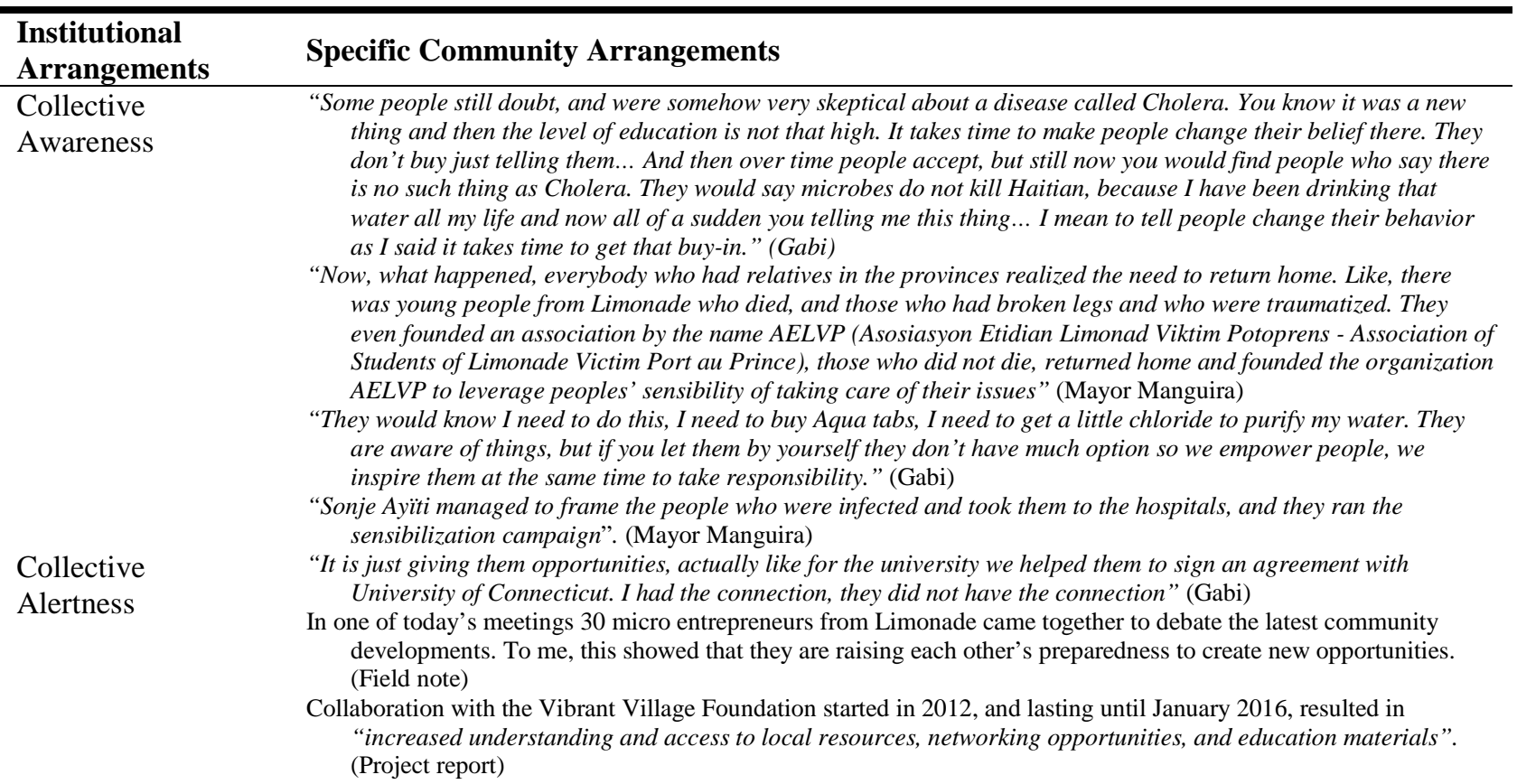


Collective Intentions

\section{Collective Trust}

\section{Collective Vision}

\section{Temporary}

Material Solution

Enduring Physical Infrastructure
Gabi showed me pictures of a child from Limonade who was sent to the US to receive a surgery nobody was capable of performing in Haiti. She also explained their talks with doctors to develop specialized health treatments. We then drive to meet with a dentist who plans to set up a professional clinic. (Field note)

" $M-C A D$ partners are growing crops to help supply fresh food for the new Restaurant and Supermarket in Dubout, across from the new Henri Christophe University. New plans are being made to grow a high-yield strain of corn for use as a significant cost-saving measure for the SAPENSA Poultry farm feed, and to add much-needed nutritive value to the local communities, as we as the very high value habanero pepper varieties." (SAPENSA documents)

"So that's after the earthquake, we were able to help RAFAVAL with the cocoa factory, now we are helping them with the bakery. And then with our network we talked to the former director Theodate, so they are able now to sell the chocolate inside the university, which brings more income for them. We wanted to do more, as far as education, we are planning and more focusing on university-level help to help students to have access to university just through sponsorship. If the earthquake had not happened, maybe we would not have intended to build that CIMA community school although the need was there, but before we did not want to get into that." (Gabi)

"Partnerships, the result multiplies when you build partnerships. If the university infrastructure is there, I don't have to go elsewhere. All the 3000 students, by working to them, by giving them a place where they can do hands-on work; I mean I learn, they learn too. I think partnerships to us is a win-win situation. Building partnerships helps us to broaden our vision. Because at the end of the day it is not about you, you are working for the community". (Gabi)

Today I met several representatives from the university, who explained their increasing network of partners in Limonade and the greater North of Haiti, who intend to increase the number of internship positions for students. They share the same vision to develop the skills of workers, and so to foster local production. (Field note)

"We had the so called 'kata', which is a 'Haitian konbit', putting our heads together or work party activity so that we build trust and exchange more our ideas" (Mayor Manguira)

"Back in the days, as kids we used to play, like when you live in a neighborhood like this, you did not have to have this big fence, because you were just that big Lakou, where everybody can play at night. The parents would sit on the patio and that's how Cap-Haitian was build and then you would play Krik-Krak, telling you tales, but we are losing this type of things. I think the earthquake in a sense helped to develop that, helped people to remember who they are as Haitian, some of the values we tend to loose, they kind of help us to remember and to work together to develop that trust again." (Gabi)

During the construction of eco-toilets, we were able to leave the materials on side, trusting that people living next door would guard them over night. I did not expect this to be possible, as I had heard in discussions with international NGOs that they had to fence and lock up all their materials. In the Sonje Ayiti eco-toilet project, materials were left for weeks, and nothing disappeared, which showed me the great level of trust that had developed in the neighborhood. (Field note)

Several community members have developed trust in Sonje Ayïti, Rafaval and some other local organizations, like Jonas, who says that "They trust me, I trust them. We collaborate."

"I mean, as I told you, there is no leader without people with a vision to lead. [...] To me, if there are no dreams, no collective dreams there is no need for much guidance. (Steve)

"Our vision, we want to, like for the Coco-project, it's mainly Rafaval, Rafaval is the women group we work with, and when I test the hot chocolate I see potentials. When people like you come and I serve that, you say, haaaaa, this is gourmet chocolate, and I say that has potential and I know we can use that to better empower Rafaval. Instead of coming to Sonje Ayiti all the time, they are the producer, but we can purchase from them and make them earn more money out of making those cocoa. And then themselves they can generate enough revenue to invest in humans instead of waiting for Sonje Ayiti" (Gabi)

"But after Cholera, doing water distribution and everything, we spent much of time doing that and try to see education is key on everything. So we said if we want to continue to empower those people to get out of poverty, they need to be healthy. So it is really a holistic approach. You see that you have been doing more that was not really our main focus." (Steve)

“There was no shelter. I mean some churches, but they don't really have the capacity to keep people... So, every individual inhabitant were obliged to provide shelter for the newcomers. Like, Sonje Ayïti would came to see you and if you have a house they would ask you to provide shelter for a group of people." (Patrick)

"How did we organize housing for the people - let's say that for example I had my parent's house, which was big, so we put some people there, and for instance in the in the peasant environments we looked for community leaders who were aware of bigger houses in the area, and there were also some churches and school on the list." (Mayor Manguira)

"They came them from Cincinnati and we were provided mobile clinics for those who did not have. We also hired a psychologist for 3 months. Those people who lost family members and who were traumatized, so the psychologist Margarette did work with them 1-on-1, like 3 days a week would go and have sessions, group-sessions, and some of them would require one on one type of attention" (Gabi)

Ernise explains at the local school in Cima ( $1^{\text {st }}$ section of Limonade) that everybody in the community knows that educating under a makeshift tent is not the way it is supposed to happen, but currently the only option to provide any kind of schooling for that neighborhood. (Field note)

"Set up 16 Oral Rehydration Ports (ORP) to prevent further spread of cholera throughout Limonade and community home visits to sensibilize the population about proper hygiene and importance of safe drinking water" (Sonje Ayïti project report)

As part of their community development funding, USAID has provided a 200000 USD subsidy to SAPENSA in order to build an abattoir that would create employment on-site, but even more important in the retail of chicken meat. "The chicken farm has been a big thing for the population... There were people who were creating commerce by buying and selling chicken. There were also people working on the farm and benefiting of the job" (Jonas). The processing site will sell chicken packaged into smaller pieces, which directly addresses a major social problem, that is most Haitians cannot afford to buy an entire chicken at once. Sold in smaller portions many citizens could get better access to protein rich chicken. (Field note) 
In my fourth trip at the elementary school in Cima, I observed that the make-shift tent, which was first replaced with a wooden structure with roofing made out of recycled metal sheets, has been replaced with a permanent, concrete building. (Field note)

The Caracol industrial park and the improved road network add to the physical infrastructure. Before the earthquake, industrial activity was marginal and the needed road and electricity infrastructure did not yet exist. (Field note)

Students tell me that the university complex affects everybody in Limonade. All the young people want to attend, receive the government scholarship, and then develop Limonade. (Field note)

Table 2b. Illustrative examples for institutional work practices in Limonade

Institutional
Work Practices

Advocating

Emergent Roles

Assessing Needs

Improvising

Leading

Reflecting

Collaborating

Valorizing

\section{Post-Disaster Activities}

"We find ways to responsibilize them, this is not a handout, you work for it, and this is your contribution, you need to participate in it." (Gabi)

"We had the so called 'kata' which is a 'Haitian konbit', heads together or work group activity. We had that in Limonade." (Manguira, Major of Limonade)

"In the process against cholera Sonje Ayïti took in their hands to help the population. I was educated as an advocator, to go on the field to inform people on what cholera is, and how to prevent cholera from making more damages in the community." (Wances, university student)

"It's a pleasure for us to help, but it can also happen that we will look for other people to help us do our job." (Jonas, Sonje Ayïti worker)

"We go to the community, we sit with them, we assess their needs, we ask questions, they ask us questions. And based on that we see what program might be more appropriate for them and then we work with them." (Gabi)

"We have been doing some water testing where we discovered most of the water we tested, 98\% of them had E-coli. And now we are trying to mobilize resources so we can provide long term solutions." (Gabi)

When 15 orphaned children arrived in the Cima neighborhood, the Rafaval cooperative and Sonje Ayïti looked for schooling possibilities, and found none. They drafted a plan of resources needed to open a school inside the community. (Field note)

"We are currently managing 16 oral dehydration posts, where we got suppliers from our partners like Unicef, like Soap, Clorox, Aqua tabs." (Gabi)

Gabi and Steve organized neighbors to build tables and chairs for a school: We met unpaid women (untrained teachers) teaching under a UNICEF-tent to all-ages simultaneously, for whom the entrepreneurs organized donations. (Field note)

Gabi and Steve hired a psychologist and adjust the interior of an old school-bus to open a medical clinic that could go even to the most rural parts of Limonade. (Field note)

"We involve in bettering the roads, we involve in, if employees are sick who do not have a healthcare system, making sure that they go to the doctors. Making sure that we pay for it, so that we can help." (Steve)

"Sonje Ayïti opened information posts, and I worked as an information agent, going from door to door, explaining to the people what kind of precautions concerning general hygiene to take, and in case there is an infected member in the household what measures to take to bring the person under care." (Wances)

The Mayor sent busses to Port-au-Prince to bring survivors out of the collapsing capital. When they arrived in Limonade several NGOs and foreign organizations working in the area were willing to help. The Mayor stresses that until Sonje Ayïti started to coordinate and lead activities for survivors to settle in Limonade, the provision of help was chaotic. (Field note)

"In the past, we used to do mobile clinics, but we say that it's a lot of resources, we focus our efforts now mainly on health promotion." (Gabi)

"They [Sonje Ayïti] organized and re-organized, and re-organized, and re-organized, and re-organized, as I have watched them, and I have known Gabi since about 2009, and if it doesn't work they do something else." (Dr. Wolff, Director of Meds-for-Kids)

Steve realized that selling whole chicken on the market was unaffordable for a large part of the Limonade community. Thus, SAPENSA decided to halt the chicken production and build an abattoir to process the meat and be able to sell smaller portions at lower prices. (Field note)

"We manage a microcredit program which is called Koud-A-Koud, for us literally Koud-A-Koud means shoulder-toshoulder [...] we provide like five trainings to the applicants, and we organize them into solidarity groups and all of them are a kind of mentor for one another." (Gabi)

"Right after the earthquake we partner up with the Ministry of Health, Konbit Santé and Haiti hospitals.” (Gabi)

Meds-for-Kids, a US American non-profit organization dedicated to the treatment and prevention of childhood malnutrition in Haiti, has its production in Limonade. For reaching families in the rural areas they need the help of Sonje Ayïti and Rafaval, because they fellow Haitians trust them and they have the cultural knowledge needed for motivating the families to participate in the program. (Field note)

The Dominican Republic donated a university building to Limonade, however it remained unused for more than a year due to lack of funding for professors and build curricula. Gabi and Steve contacted foreign universities to build partnerships to teach/train both staff and students. (Field note)

"The employees are the reason why I am here, because this is part of the local movement to a better future for not only them, myself, and the region as a whole." (Steve)

"Encourage them to stay in the village, to be there to help raise the families, instead of going to the Dominican Republic." (Steve)

"You will benefit from two or three pregnant goats. We don't just give that to you, we have to responsibilize them. We give that to you; we also ask you to sign a contract. You receive three female pregnant goats, you have up to a year to return three baby goats, so we can transfer to someone else in the communities." (Gabi) 
Synergizing

Educating

Mobilizing Engagement
"We need to start producing, we need to start planning so we can produce rightfully for the people so we can start thinking about producing first, quality we will think of as we move ahead, as we experiment, as we gain more experience." (Steve)

"The Koud-A-Koud micro loan program helps people to make a little commerce, so they can have more income and send all their children to school." (Ernise, CEO of Rafaval)

"They [Sonje Ayïti] supply RAFAVAL with goats and we distribute them to parents to help families to advance. Besides that, they also help us in the field of education, because it's them who find us the teachers and pay for them, and it's also they who give us the school materials." (Ernise)

"When producing we look at production first, but we look at how the production really connects to other activities, for example we looking at producing 200000 egg layers, but what you have to take into consideration is the fact that by producing egg layers you have to have access to animal feed, so while we are producing eggs, using egg layers, we will facilitate the regional planters to grow corn which represents 50-60\% of the animal feed used in the production of eggs." (Steve)

"Since we are neighbors [with Anba Tonel], I have promised, that in any discipline that they have needs, we are ready to collaborate. Whether it is in animal herding or wherever, we are ready to support.” (Vilna, university teacher)

"People used to wash their hands, but before the education [from Sonje Ayiti] they didn't wash them with soap and treated water." (Sonson, Sonje Ayïti worker)

"We used to provide seeds for them and training, and now we have invested on 15 acres where we are doing horticultural farms." (Gabi)

The new university in Limonade currently provides education for 1000-1500 students a year. In their third and final year, every student needs to do a hands-on internship in an organization. Most students look for opportunities directly in Limonade. (Field note)

"We are trying to get the local involved, we have to better what Patrick says earlier, the level of technology, but we don't want to automate the agriculture in a way that the planters are left out." (Steve)

"If we together conjugate our efforts to empower Haitians, teach Haitians to teach Haitians so that they can rebuild their country." (Gabi)

"Instead of giving them some money or some shoes, even with used clothes and so forth, you know, I don't give out those types of things anymore. Instead of that, why don't we have a little street store, you employ some women in the communities. [...] We might be there for 10 years, but when we leave Limonade we need to see tangible results." (Gabi)

During my daily lunch at Anba Tonel, I observe that students and teachers meet and discuss ideas on improving the situation in Limonade, the education situation and access to food. (Field note)

Steve organized the plantain farmers into a registered association. (Field note)

Table 2c. Illustrative examples for collective emotions in Limonade

\section{Collective \\ Emotions}

Feeling of

Security

Compassionate

Empathy

Collective

Confidence

\section{Shared Affective Responses}

"This made it possible for the people who had lost everything to rely on people from different organizations, like in my case [Limonade] there was a Spanish organization, which donated food and we distributed it to 1500 people. Two times we brought them big sacks of rice, oil canisters, half sacks of corn, so that they could cook their own food." (Manguira)

"Now, we looked for places to stay for the people, where they could sleep. We looked for material aid through Sonje Ayïti and other organizations. We looked for food to provide for them." (Manguira)

"If we eat, they eat, too. If we drink, they drink. We make them feel welcome, we de-traumatize them." (Patrick)

"I felt obliged to give more of my time to Sonje Ayïti, so that we were able to realize this system. Because when people have needs, say, the quartier has a lot of houses and you put 5 individuals in each house, you have to pass by to see them." (Patrick)

"Sonje Ayïti is an organization, which is always working to help the community in social affairs so that people would feel they have others who are with them, who help them and make the situation more comfortable for them." (Wances)

"In the group in which I was, I was the only guy and I had a team of young girls with me, they really worked fiercely! the experiences we had had in the field, when we reported it for the organization, they felt that we really did an enormous job." (Wances)

"We introduce them to the ways of the area and make them feel that they are inhabitants of Limonade. Whatever activities we have we incorporate them in those." (Patrick)

"The most dramatic thing that I saw was the way they [Sonje Ayïti] are approaching the micro loan projects where they are not just handing out money, but they are actually making sure that the people who get the money are supported. [...] the vision of the director Gabrielle is what is powering this. She is doing it in a way that is very different from the other two organizations I have worked with." (Mininder, a Sonje Ayïti volunteer)

"What I can say is that for every movement there needs to be a leader and as we see, we see you [Steve] as a leader, as somebody who is always looking because these didn't exist." (Alexi, community member)

"They [Gabi and Steve] have confidence in us and we have confidence in them. Because when we buy from them, we pay and we give them a good report on our activities and they get good results with us. To keep partnership functioning, there has to be confidence, there has to be respect on both sides along the lines. ” (Ernise)

"My dream is for this country to move ahead. I mean the way for this country to move ahead, is for us to create more jobs and for the employees to have more knowledge of what they are doing. That's how I see the movement." (William, worker at chicken farm)

During the fourth trip, two student teams approach me and for the first time they actively seek counseling on business ideas they develop, both seeking to establish social enterprises to eradicate illiteracy in Limonade. (Field note) 
Harmonious

Passion

Affective

Solidarity

Collective Hope
Jonas, an accountant from Limonade, explains that the community has learnt that it can handle major obstacles. After the earthquake excepted 5000 refugees into their homes, often 23 staying in one family, but after 3 years most people have safely returned to Port-au-Prince or build their own home. (Field note)

"We are still with the school in Cima, at the moment we are in the 4th year. And every year we have to put a new class, like next year we are going to have 5th grade. To have this program Sonje Ayïti is helping us, they are paying the teachers for us, finding materials for us so that the children can go to school, and food." (Ernise)

"Since the presence of Sonje Ayïti, Talon in the leading place in the area. Finally, this helped our life to change. Myself personally, I became a capable person with Sonje Ayïti. This has allowed me to prepare a lot of young people, send them to study, got telephones for them, supported them financially to do things. I have seen a change." (Patrick)

"Here everybody has understood that Sonje Ayïti is a source, it's a passionate motor for our community. They make canalization, a series of things, accompany little children and provide resources for them. In another word, people have faith, that when Sonje Ayïti has something they plant it with the community." (Patrick)

During the fourth field trip, I enquire the status on Rafaval's operations. The director is excited to share the success of the cold chocolate milk plant, and passionately explains their new idea to build the first bakery in town. (Field note)

"Yes, because we showed people that it's the collectivity which is important. Because after all the efforts - and we did all the efforts together - we showed them that we have the will. Sonje Ayïti had a team which didn't sleep, they worked day and night. And when we finished working we met with the people and we said: today we have given them life, we wish that tomorrow they will give us life through their collectivity. If they will not work together, it will show us that our efforts were in vain." (Patrick)

"Without Sonje Ayïti nobody would take care of our situation [...] the city has no money to help all our people. Sonje Ayïti makes us believe that we can still do it." (Manguira)

"Based on what has been realized already we can state that the community in general collaborates with them in their vision and objectives." (Wances)

"I think also what stood out to me beside of all the worriedness, was a sense of solidarity. Because even they did not know somebody when they came to the community they would welcome you... That sense of solidarity to me was very strong that really reminds me who we are as Haitian" (Gabi)

"I urge you to join in this journey to give Haitians a reason to stay in their country, to create a Haitian dream that all can strive to reach, and eventually restore this island into what it was once before the Pearl of the Caribbean. We will rebuild, to the least we will bring hope, pride, and dignity back." (Gabi)

"We just have our first year of business and we are moving into the second year. In spite of the difficulty we are facing, the local populations are related about what's going on. This is the first time they see from nothing somebody is trying to make, a group of people is trying to make a change with the locals, the small resources available to them. Even, despite the loss of hope that 2010 brought, small initiatives like that, a lot of us are regaining hope." (Patrick)

The Rafaval cooperative is attracting more and more women to join, as they are hopeful that eventually the cooperative will be able to build a chocolate factory and have a product to sell, which would create some income so that they can afford school uniforms to send their children to school.

On the construction side, the workers proudly wear the yellow t-shirts, and some even bring white ones from earlier projects with Sonje Ayïti. All shirts display in bold letters the main slogan 'Remember Haiti'. One worker explains that for him they symbolize a better future. (Field note) 
Figure 2. Data structure

\begin{tabular}{|c|c|c|}
\hline $\begin{array}{c}\text { First-Order } \\
\text { Category }\end{array}$ & $\begin{array}{c}\text { Second-Order } \\
\text { Theme }\end{array}$ & $\begin{array}{c}\text { Theoretical } \\
\text { Category }\end{array}$ \\
\hline $\begin{array}{l}\text { Localizing response; Offering food/money for work; Coordinating } \\
\text { community }\end{array}$ & $\begin{array}{l}\text { Advocating Emergent } \\
\text { Roles }\end{array}$ & \\
\hline $\begin{array}{l}\text { Evaluating idle capacity; Inquiring people's opinion; Testing } \\
\text { environmental conditions }\end{array}$ & Assessing Needs & \\
\hline Creative use of available resources; Refitting space and objects & Improvising & \\
\hline $\begin{array}{l}\text { Getting own hands dirty; Becoming a role model; Practicing } \\
\text { personal assistance }\end{array}$ & Leading & \\
\hline Joining active initiatives; Contacting potential partners & Collaborating & Insti \\
\hline Adjusting initiatives; Communicating critical reflection & Reflecting & \\
\hline $\begin{array}{l}\text { Creating community identity; Designing alternative 'worlds'; } \\
\text { Imagining concrete ends }\end{array}$ & Valorizing & \\
\hline $\begin{array}{l}\text { Intensifying mentoring; Developing curriculum with schools; } \\
\text { Formalizing training programs }\end{array}$ & Educating & \\
\hline $\begin{array}{l}\text { Activating new community efforts; Organizing new groups into } \\
\text { associations }\end{array}$ & Mobilizing Engagement & \\
\hline $\begin{array}{l}\text { Building production chains/networks; Increasing production } \\
\text { capacity; Connecting work groups }\end{array}$ & Synergizing & \\
\hline $\begin{array}{l}\text { Apprehension of communication infrastructure needs; Realization of } \\
\text { needs for better healthcare; Understanding disaster damage needs }\end{array}$ & Collective Awareness & \multirow{7}{*}{$\begin{array}{l}\text { Institutiona } \\
\text { Arrangement }\end{array}$} \\
\hline $\begin{array}{l}\text { Prepared to coordinate/join new local cooperatives; Ready to } \\
\text { organize/join new working groups }\end{array}$ & Collective Alertness & \\
\hline $\begin{array}{l}\text { Plans for specialized health treatment; Desire to initiate new NGO } \\
\text { partnerships; Wish to develop local collaborative agreements }\end{array}$ & Collective Intentions & \\
\hline $\begin{array}{l}\text { Belief in renewing food production; Belief in successful } \\
\text { empowerment programs; Belief in the power of local NGOs }\end{array}$ & Collective Trust & \\
\hline Agreement on new community goals; Expectation of a better future & Collective Vision & \\
\hline Make-shift school; Shelters; Mobile clinic & $\begin{array}{l}\text { Temporary Material } \\
\text { Solutions } \\
\end{array}$ & \\
\hline $\begin{array}{l}\text { Local office depots; Restaurants; Permanent education } \\
\text { infrastructure }\end{array}$ & $\begin{array}{l}\text { Enduring Physical } \\
\text { Infrastructure }\end{array}$ & \\
\hline $\begin{array}{l}\text { Relief of anxiety; Relaxing and calming; Bond with reliable } \\
\text { community members }\end{array}$ & Feeling of Security & \multirow{6}{*}{$\begin{array}{l}\text { Collective } \\
\text { Emotions }\end{array}$} \\
\hline $\begin{array}{l}\text { Communal self-respect; Taking perspective of others; Expressive } \\
\text { compassionate body language }\end{array}$ & Compassionate Empathy & \\
\hline $\begin{array}{l}\text { Feeling of being able to achieve change; Commitment to pursue } \\
\text { community goals; Experience of mutual benefits and capabilities }\end{array}$ & Collective Confidence & \\
\hline $\begin{array}{l}\text { Excitement to lead community development; Ambition to realize } \\
\text { specific community goals; Energized to act as a motor for change }\end{array}$ & Harmonious Passion & \\
\hline $\begin{array}{l}\text { Affective commitment to help others; Affective concern for others; } \\
\text { Feelings of belonging to community spirit }\end{array}$ & Affective Solidarity & \\
\hline $\begin{array}{l}\text { Feeling that an imagined ideal is possible; Positive experience of } \\
\text { development; Attachment to new community identity }\end{array}$ & Collective Hope & \\
\hline
\end{tabular}


Figure 3. Ernise, teaching under a tent in Limonade

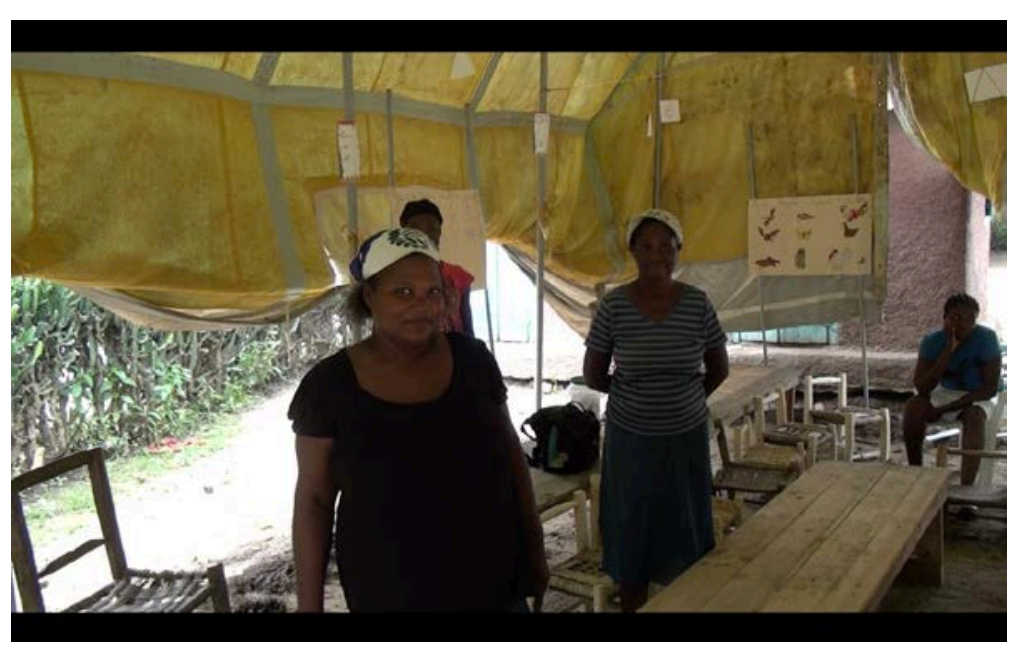


Figure 4. Observed institutional work in Limonade between 2010-2016: The examples of establishing a school (Vignette 1), Cholera response (Vignette 2), and developing a local food production chain

Phase 1: Disaster Response

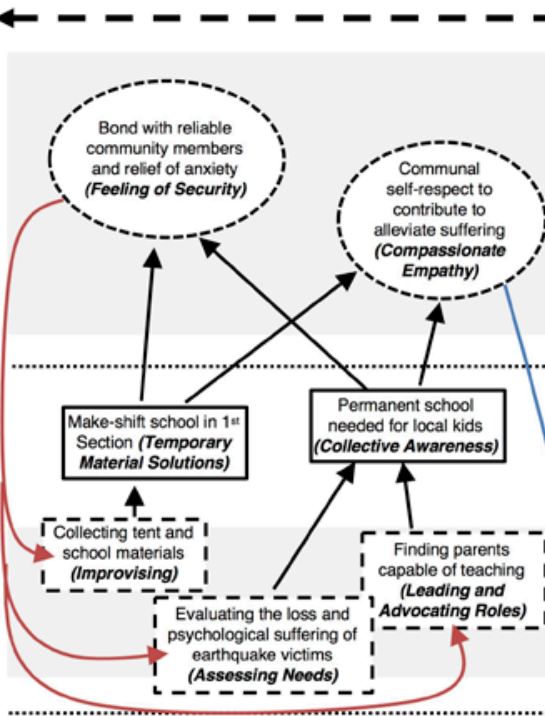

Example 1:
Schooling Story
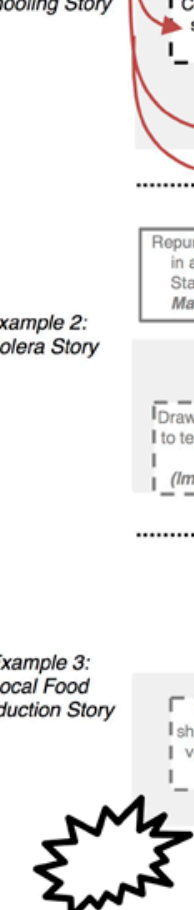

Phase 2: Disaster Recovery

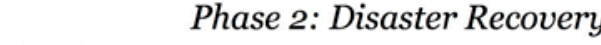

Phase 3: Disaster Reconstruction

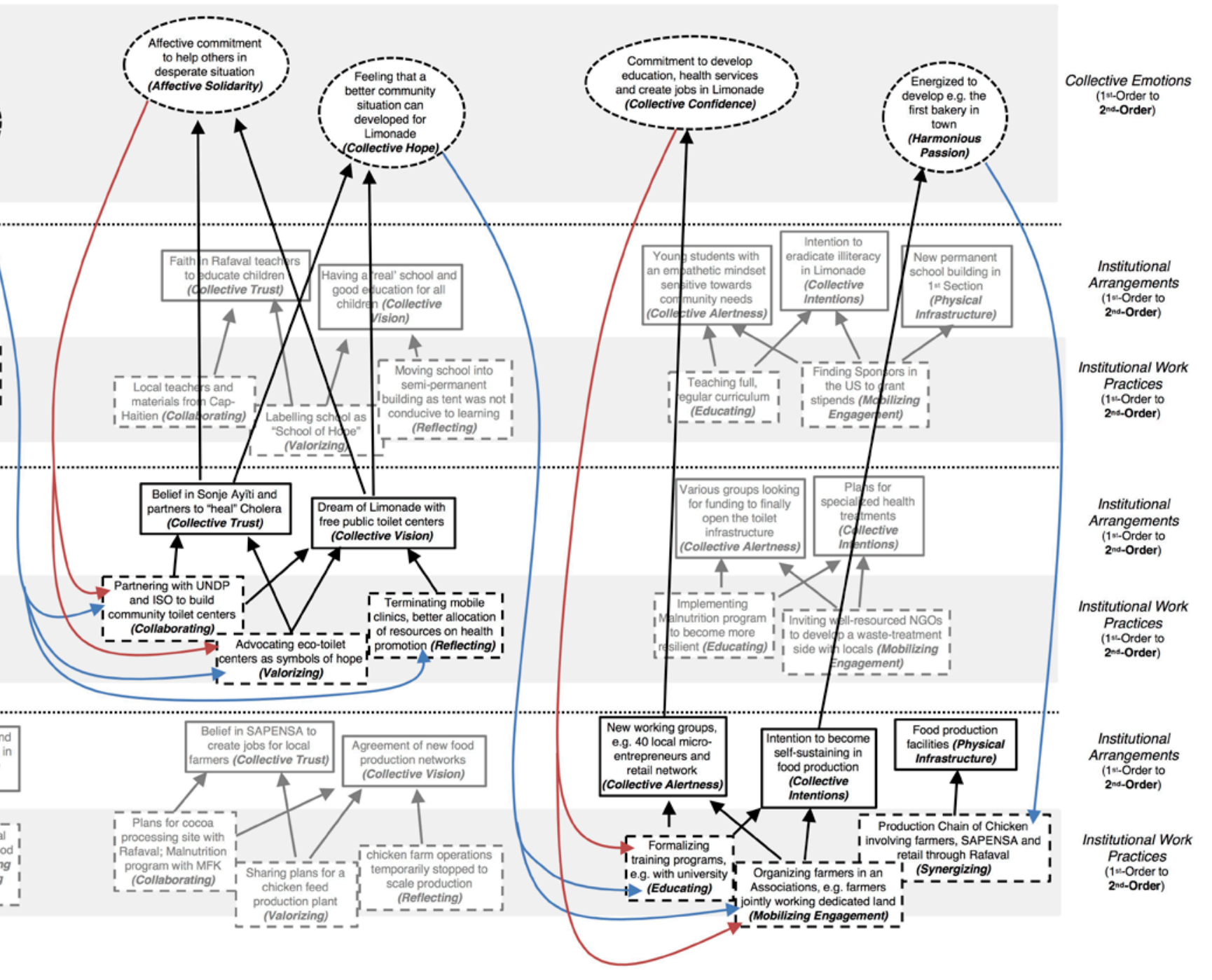


Figure 5. Local musicians celebrating the opening of the toilet center

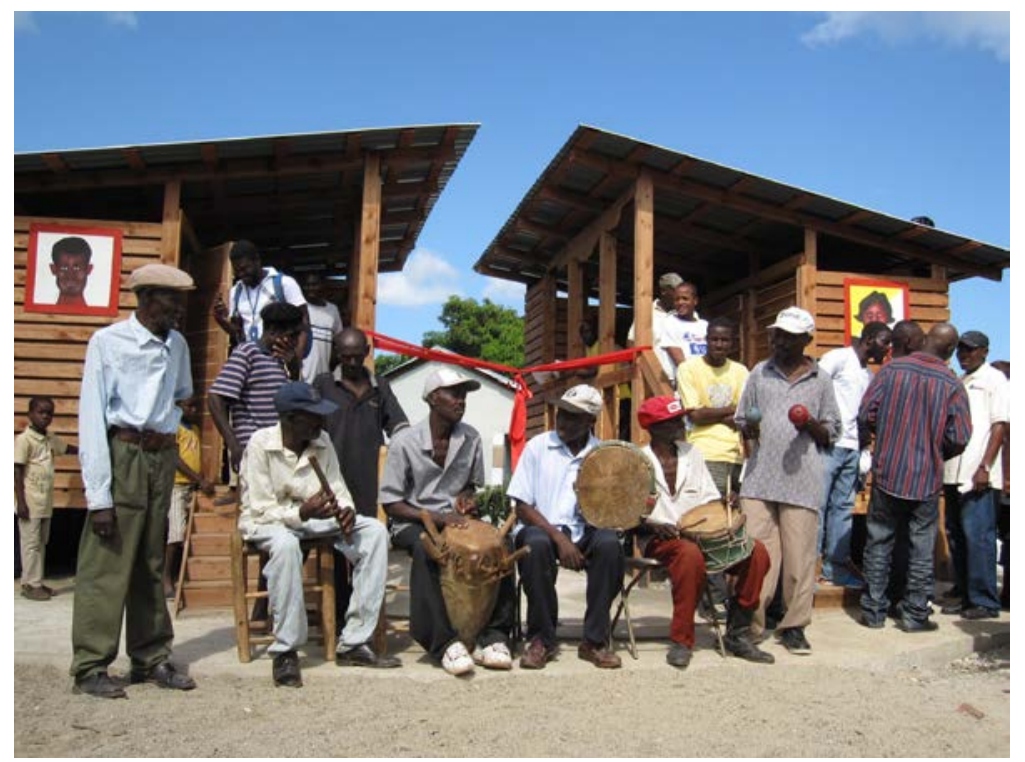

Figure 6. Cima School of Hope
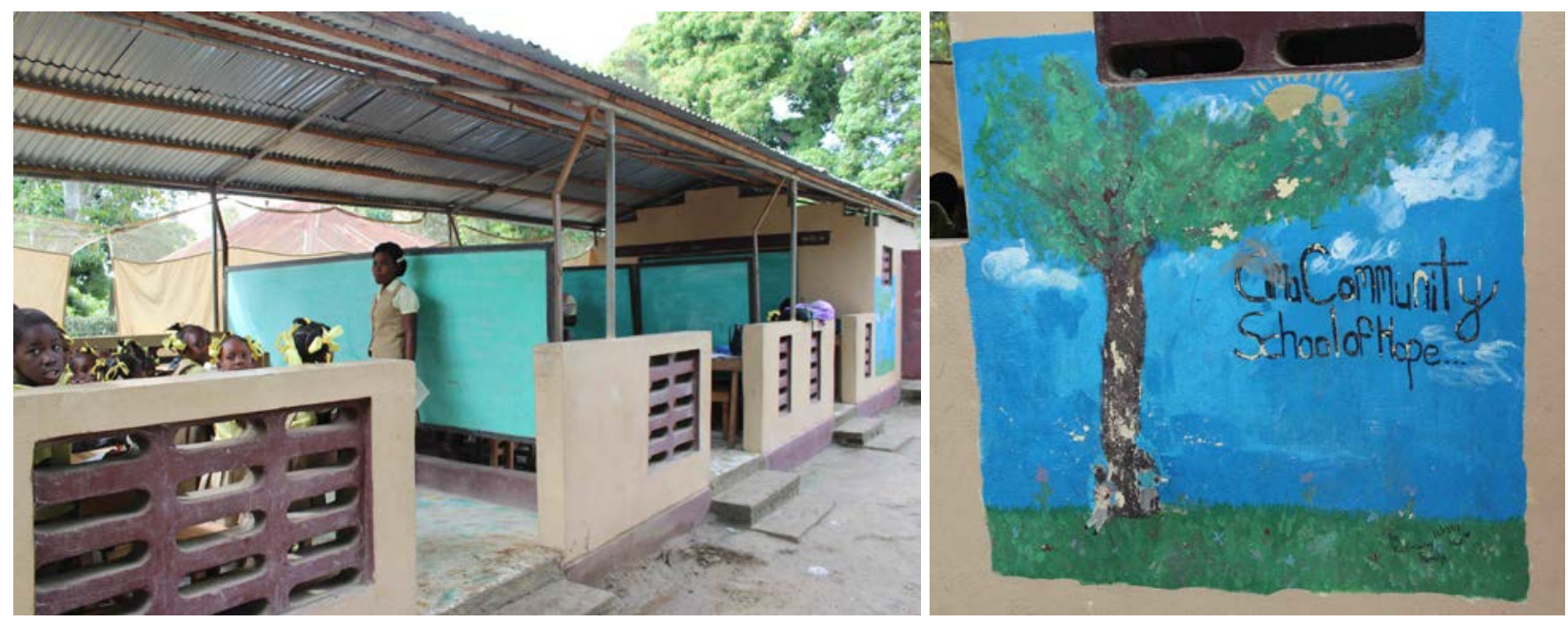

Figure 7. Agricultural fields for training the students in front of the new university

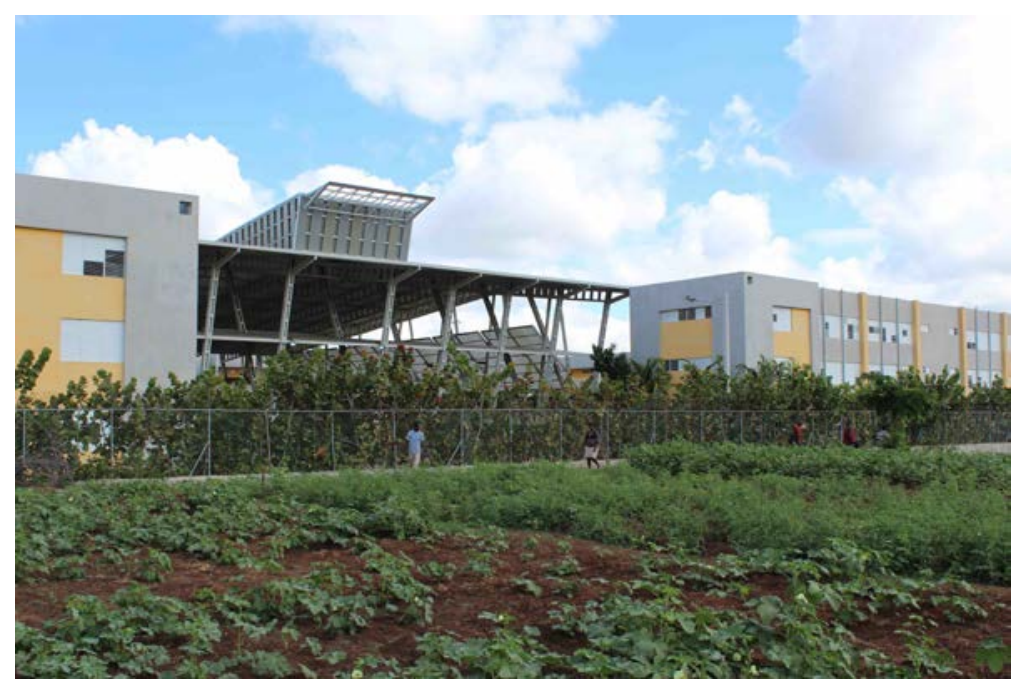


Figure 8. Gabi and Vilna observing students working on the harvest

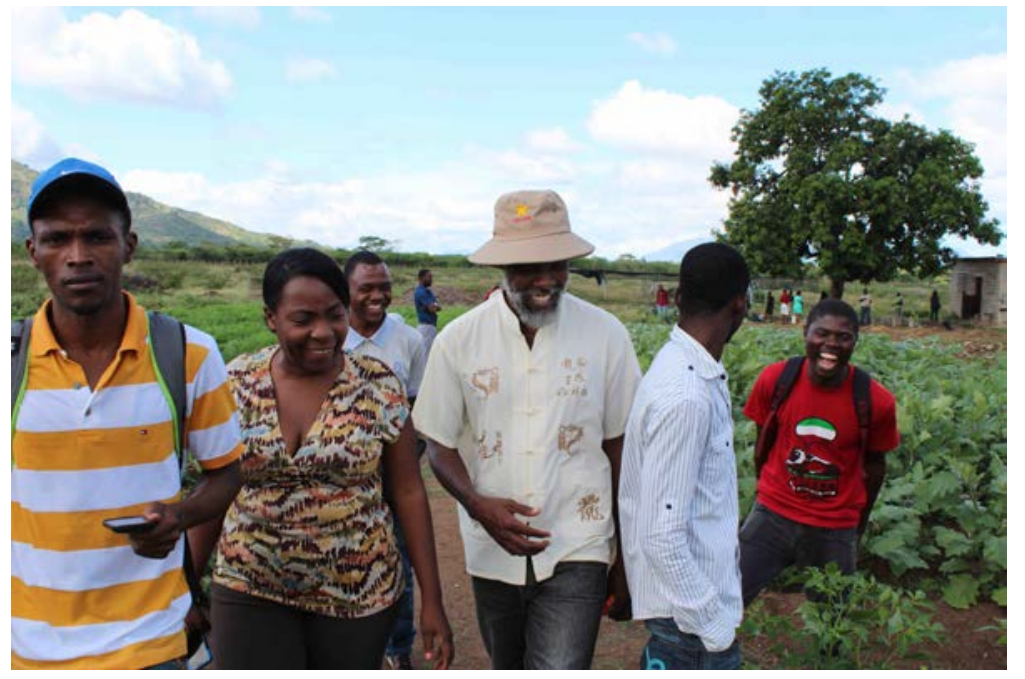


Figure 9. Institutional creation work and collective emotions across the three post-disaster phases

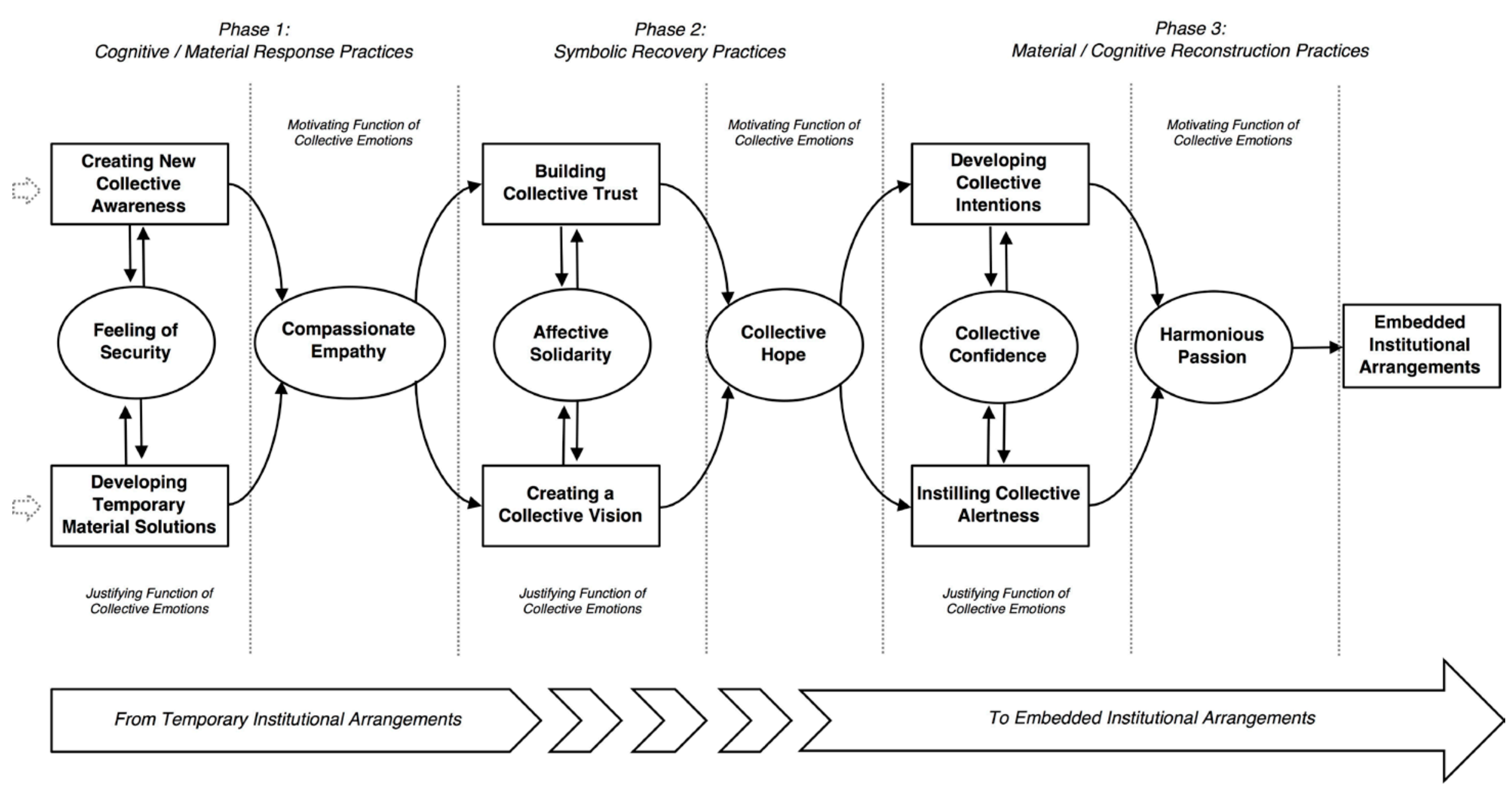


Figure 10. A generative model of collective emotions in institutional creation work

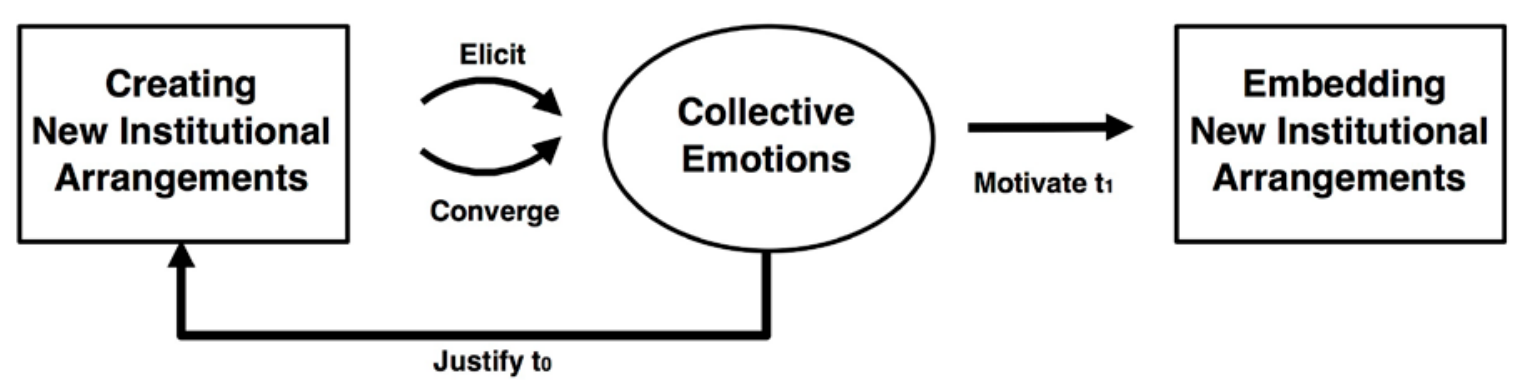

\section{Biographies}

Steffen Farny (steffen.farny@aalto.fi) is Post-Doctoral Researcher in Entrepreneurship at Aalto University School of Business, Finland. He completed his PhD in Entrepreneurship at Aalto University. His research combines institutional theory, research on emotions and entrepreneurship to investigate sustainable forms of organizing.

Ewald Kibler (ewald.kibler@aalto.fi) is Assistant Professor of Entrepreneurship at Aalto University, School of Business, and serves as Academy of Finland Research Fellow. He completed his MA in Sociology at the University of Graz, Austria, and his $\mathrm{PhD}$ in Economic Geography at University of Turku, Finland. His research interests include new venture imaginations and legitimation, place-based and prosocial business venturing, everyday community organizing and shared emotions, institutional work and regional development, and population aging and societal wellbeing.

Simon Down (simon.down@anglia.ac.uk) is Professor of Management at Anglia Ruskin University, UK. He completed his PhD at the University of Wollongong, Australia. He has researched a broad range of entrepreneurial phenomena, from an ethnography of entrepreneurial identity formation, to the impact of regulation on small business behaviours, to the identity work of Australian Indigenous entrepreneurs, and social entrepreneurship in Haiti, to the emergence of entrepreneurship pedagogy in North Korea. 